\title{
Political Parties as Mediating Institutions
}

\author{
Steven G. Calabresi†
}

The great virtue of the American structural constitutional system of checks and balances, separation of powers, and federalism $^{1}$ is that it preserves liberty by setting governmental power against itself. ${ }^{2}$ The great vice of this system is that it reduces the accountability of public officials and of the government in general by making it more difficult for the voters to know which officials and actors in the political system are responsible for any particular set of actions. ${ }^{3}$ The great debate between presidential and parliamentary forms of democratic government may thus largely come down to a trade-off between the success of the American presidential system in preserving liberty and the success of the British parliamentary system in making the government accountable for what it does. ${ }^{4}$ While there are many

$\dagger$ Associate Professor, Northwestern University School of Law. I am grateful for the helpful suggestions of Akhil Reed Amar, John Harrison, Gary Lawson, Gregg Maggs, Tom Merrill, and Dan Polsby. I am also grateful for the helpful research assistance of Christopher Rohrbacher.

1 For a brief description of our structural Constitution, and an attempt to contrast it with the explicit, individual-rights-protecting features of the document, see Steven G. Calabresi and Kevin H. Rhodes, The Structural Constitution: Unitary Executive, Plural Judiciary, 105 Harv L Rev 1153 (1992). See also Akhil Reed Amar, The Bill of Rights as a Constitution, 100 Yale L J 1131, 1132, 1191-1201 (1991) (persuasively criticizing the in many ways artificial separation between the structural Constitution and the Bill of Rights).

2 As James Madison said so vividly, "Ambition must be made to counteract ambition" so that "the private interest of every individual may be a sentinel over the public rights." Federalist 51 (Madison), in Clinton Rossiter, ed, The Federalist Papers 320, 322 (Mentor, 1961). For a short comment on the theory of human nature that underlies American constitutionalism (and economics), see Steven G. Calabresi and Gary Lawson, Foreword: Two Visions of the Nature of Man, 16 Harv J L \& Pub Policy 1, 1-5 (1993).

3 As Lord Bryce colorfully described matters:

[W]ill not a scheme, in which the executive officers are all independent of one another, yet not subject to the legislature, want every condition needed for harmonious and effective action? They obey nobody. They are responsible to nobody .... Such a system seems the negation of a system, and more akin to chaos.

James Q. Wilson, Political Parties and the Separation of Powers, in Robert A. Goldwin and Art Kaufman, eds, Separation of Powers-Does it Still Work? 18 (American Enterprise Institute, 1986), quoting James Bryce, 1 The American Commonwealth 530 (Macmillan, 3d ed 1895).

- For a nice, short introduction to that venerable and great debate, see Arend 
other factors to weigh in choosing between presidential and parliamentary government, this trade-off between liberty and accountability is, in my judgment, the key choice. ${ }^{5}$

There is a widespread view, however, particularly popular in some political science circles, that political parties may be able to overcome (to some degree) the defects of American-style separation of powers by acting as a mediating institution that will allow the voters to hold both Congress and the President accountable for a particular political platform. ${ }^{6}$ The idea is that the party system might be able to "overcome the separation of powers by bringing together under informal arrangements what the founders were at pains to divide by formal ones." Many who advocate this view think that political parties once played more of a mediating role in American political life than they do presently and that this was a good thing. ${ }^{8}$

Accordingly, some argue that numerous recent legal developments have fatally undermined American political parties and thus prevented them from playing their vital mediating function of providing accountability, notwithstanding our constitutional system of separation of powers. ${ }^{9}$ Others have gone beyond this to urge the adoption of fundamental constitutional reforms that would strengthen political parties and make it easier for them to overcome the constitutional separation of powers. The most prominent exponent of this view is Lloyd Cutler, the once and future White House Counsel, who is surely one of the most politically prominent and successful legal thinkers of the last thirty years. ${ }^{10}$

Lijphart, Introduction, in Arend Lijphart, ed, Parliamentary versus Presidential Government 1-27 (Oxford, 1992).

5 Id at 12-20. Professor Lijphart lays out these other factors quite nicely. As he explains, "Presidentialism is said to have the advantages of executive stability, greater democracy, and more limited government, but the disadvantages of executive-legislative deadlock, temporal rigidity, and less inclusive 'winner-take-all' government. Parliamentarism is said to have the opposite consequences: the advantages of presidentialism are its disadvantages and vice versa." Id at 11.

6 See James MacGregor Burns, The Deadlock of Democracy: Four Party Politics in America 323-40 (Prentice-Hall, 1963); E.E. Schattschneider, Party Government 206-10 (Holt Rinehart, 1942); American Political Science Association, Committee on Political Parties, Toward a More Responsible Two-Party System, 44 Am Pol Sci Rev supp 1, 15-18 (1950); James L. Sundquist, Constitutional Reform and Effective Government 230-77 (Brookings, rev ed 1992).

7 Wilson, Political Parties at 18 (cited in note 3).

8 Id at 19-26.

9 Ralph K. Winter, "The New Age of Political Reform": Looking Back, 15 Ga L Rev 1 (1980); Alexander M. Bickel, The New Age of Political Reform: The Electoral College, the Convention, and the Party System (Harper, 1968).

${ }_{10} \mathrm{Mr}$. Cutler served as White House Counsel to former President Jimmy Carter and 
Mr. Cutler has proposed a whole host of reforms that would strengthen political parties and weaken the separation of powers. ${ }^{11}$ In particular, he has proposed requiring voters to vote for candidates of the same political party both for President and for Congress, so as to "tie the political fortunes of the party's presidential and congressional candidates to one another and give them some incentive for sticking together after they are elected." In the same vein, he has urged amending the Constitution "to permit or require the president to select 50 percent of his cabinet from among the members of his party in the Senate and the House" while allowing those members to "retain their

now holds the same post under President Clinton. He is a name partner of a major Washington law firm (Wilmer, Cutler \& Pickering) and has played a leading role in American public life for many years. Mr. Cutler was heavily involved in marshalling support for the failed Supreme Court nomination of former United States Court of Appeals Judge Robert H. Bork, see, for example, Lloyd N. Cutler, Saving Bork From Both Friends and Enemies, NY Times A27 (July 16, 1987), and he actively lobbied on behalf of his former employee, Zoe Baird, during her unsuccessful bid to become President Clinton's first Attorney General. See Michael Isikoff, Is Baird's Initial Luster Fading? Illegal Alien Issue Adds to Doubts About Attorney General-Designate, Wash Post A1 (Jan 16, 1993). A close personal friend and aide of Mr. Cutler's, C. Boyden Gray, served as White House Counsel to former President George Bush. Mr. Cutler also served on the recent Commission that ultimately succeeded in legislating an increase in congressional and judicial salaries. He has been described as the quintessential inside-the-beltway Washington lawyer-a legal spokesman for the Washington Democratic Party power elite. Mr. Cutler is a founder and co-chairperson of the Committee on the Constitutional System ("CCS"). The CCS, formed in 1982, has proposed several constitutional reforms intended to remedy alleged defects in the American system of governance. According to Donald Robinson, the CCS does not necessarily endorse any or all of these reforms, but merely hopes that these proposals will encourage public deliberation over the ability of our current system to provide effective and accountable government. Donald L. Robinson, Preface, in Donald L. Robinson, ed, Reforming American Government: The Bicentennial Papers of the Committee on the Constitutional System xiii-xvi (Westview, 1985).

11 For an explanation and defense of Mr. Cutler's proposals, see Lloyd N. Cutler, To Form a Government, in Robert A. Goldwin and Art Kaufman, eds, Separation of Powers-Does it Still Work? 1 (American Enterprise Institute, 1986); Lloyd N. Cutler, Some Reflections About Divided Government, 18 Pres Stud Q 485 (1988); Lloyd N. Cutler, Now is the Time for All Good Men ..., 30 Wm \& Mary L Rev 387 (1989). For responses to, and criticisms of, Mr. Cutler's proposals, see Philip C. Bobbitt, The Committee on the Constitutional System Proposals: Coherence and Dominance, $30 \mathrm{Wm} \&$ Mary L Rev 403 (1989); Erwin Chemerinsky, The Question's Not Clear, But Party Government is Not the Answer, $30 \mathrm{Wm}$ \& Mary L Rev 411 (1989); Thomas O. Sargentich, The Limits of the Parliamentary Critique of the Separation of Powers, 34 Wm \& Mary L Rev 679 (1993); Steven G. Calabresi and Joan L. Larsen, One Person, One Office: Separation of Powers or Separation of Personnel?, 79 Cornell L Rev (forthcoming July 1994); Mark P. Petracca, Lonce Bailey, and Pamela Smith, Proposals for Constitutional Reform: An Evaluation of the Committee on the Constitutional System, 20 Pres Stud Q 503 (1990). But see James L. Sundquist, Response to Petracca-Bailey-Smith Evaluation of the Committtee on the Constitutional System, 20 Pres Stud Q 533 (1990).

12 Cutler, To Form a Government at 13. But see Cutler, 18 Pres Stud Q at 490 (calling this proposal "unfeasible"). 
seats while serving in the cabinet." ${ }^{\text {13 }}$ Underlying both proposals is a preference for "Party Government," which would bridge the gaps created by the separation of powers and tie a majority coalition of American voters to the government they had empowered.

Mr. Cutler's advocacy of political parties as mediating institutions, and of parliamentary government, has a long and distinguished American pedigree. ${ }^{14}$ Woodrow Wilson, among others, shared Mr. Cutler's view, at least early in his career. ${ }^{15}$ Moreover, the view that political parties play a desirable mediating role in democratic governance generally has been enshrined in the constitutional law of other major Western democratic states. Thus, it has been said that the German Basic Law ${ }^{16}$ creates a party-based state. ${ }^{17}$ Article 21 of the Basic Law goes so far as to declare that "political parties shall participate in forming the political will of the people," thus "virtually certifying them as the chief agencies of political representation in the [German] polity."

The view, then, that political parties as mediating institutions are a good thing is one that is widely held and influential both in this country and overseas. But, ironically, it is a view that was rejected by the Framers of our Constitution, who repeatedly warned against the evils of "faction"19 and "the danger of

${ }_{13}$ Cutler, To Form a Government at 13-14 (cited in note 11). For a detailed critique of this particular proposal, see Calabresi and Larsen, 79 Cornell L Rev (cited in note 11).

${ }_{14}$ Henry Jones Ford, for example, defended American political parties at the turn of the century because they mitigated the accountability-reducing effects of the separation of powers. See Wilson, Political Parties at 19 (cited in note 3).

15 See Woodrow Wilson, Congressional government: $A$ study in American politics (Meridian, 1956) (first published 1895). See also Carl McGowan, Congress, Court, and Control of Delegated Power, 77 Colum L Rev 1119, 1119-20 (1977) ("[T]hat young and rising academic star in the field of political science, Woodrow Wilson-happily unaware of what the future held for him in terms of successive domination of, and defeat by, the Congress-despaired in the late 19th century of the weakness of the Executive Branch vis-àvis the legislative, so much so that he concluded that a coalescence of the two in the style of English parliamentary government was the only hope."). Wilson's views moderated later in his life. See, for example, Arthur S. Link, Woodrow Wilson and the Progressive Era: 1910-1917 10 (Harper \& Bros, 1954).

${ }^{16}$ This is the term used to refer to what is now, in effect, Germany's apparently permanent Constitution.

17 Donald P. Kommers, The Constitutional Jurisprudence of the Federal Republic of Germany 40-41, 55, 88, 190, 210-16, 227 (Duke, 1989) (discussing the Basic Law's creation of a "parteienstaat" or "party state").

18 Id at 40 (emphasis added).

19 See, for example, Federalist 10 (Madison), in The Federalist Papers at 77-84 (cited in note 2) (warning against the "violence of faction" and discussing how its "mischief" can be cured). 
parties in the State." ${ }^{20}$ The Framers of the U.S. Constitution deliberately set up our constitutional regime so that it would be inimical to the spirit of "faction" or of "party" - two terms that they tended to equate. ${ }^{21}$ It is striking that George Washington, the preeminent leader of the Founding generation, and the founder of the Federalist Party, used his famous Farewell Address to condemn parties and factions, while praising what we might call religious, moral, and educational mediating institutions. ${ }^{22}$ Jefferson and Madison, as well, who were together the founders of the world's oldest political party, ${ }^{23}$ were equally opposed to the idea of party government. ${ }^{24}$ It is a great historical irony that the same men who wrote what has been called "A Constitution Against Parties"25 were themselves responsible for creating our great national two-party system.

This great historical irony, coupled with White House Counsel Lloyd Cutler's much-discussed calls for constitutional amendments that would create an American parteienstaat, suggests that it is worth giving some thought to the potential role of the American political party as a mediating institution. In particular, I think it important to decide whether it is desirable to strengthen political parties, in the ways that Cutler proposes, so as to overcome the separation of powers and provide accountability. For reasons I will explain below, I do not believe such a strengthening is desirable, and I strongly suspect that Cutler's proposals, if adopted, would produce countless undesirable side effects. I think my analysis here, in turn, suggests the limits of mediating institutions, and the extent to which mediating institutions, more generally, are a good idea. I cannot in this short

${ }^{20}$ George Washington, Farewell Address, in James D. Richardson, ed, 1 A Compilation of the Messages and Papers of the Presidents 218 (US Congress, 1900).

${ }_{21}$ See Richard Hofstadter, The Idea of a Party System 10-11 (California, 1969); Giovanni Sartori, 1 Parties and party systems: A framework for analysis 11-12 (Cambridge, 1976).

${ }_{22}$ Washington, Farewell Address at 218-20. For example, Washington warned against the "spirit" of party that "is inseparable from our nature, having its root in the strongest passions of the human mind. It exists under different shapes in all governments, more or less stifled, controlled, or repressed; but in those of the popular form it is seen in its greatest rankness and is truly their worst enemy." Id at 218. On the other hand, Washington praised "religion and morality," saying that "[o]f all the dispositions and habits which lead to political prosperity, [they] are indispensable supports." Id at 220.

${ }^{23}$ The Democratic-Republican Party, founded by Jefferson and Madison, became the modern, popularly based Democratic Party under President Andrew Jackson.

24 See Hofstadter, Party System at 24-29. John Adams, Jefferson's fierce partisan opponent and, later in life, his close friend and correspondent, is described as sharing Jefferson's and Madison's antipathy to party government. Id at 28.

${ }^{25}$ The phrase is Richard Hofstadter's. Id at 40. 
Article hope to answer definitively the questions I am about to address. But I do hope to raise some previously neglected questions that are worth asking, and begin to sketch out some future areas of analysis.

Section I of this Article sets forth some important background considerations that are essential to thinking about the problem of political parties as mediating institutions. These considerations include the reasons that explain the Framers' antipathy to political parties and a discussion of how that antipathy could sometimes coincide, as it did in Washington's case, with a general sympathy for many other forms of mediating institutions. Section II then explains the ways in which the Framers' Constitution is truly "A Constitution Against Parties." More than we commonly realize, the Framers' Constitution truly makes the task of constructing party mediation almost impossibly difficult. Finally, in Section III, I attempt to sketch out some partial explanations as to why Lloyd Cutler's proposals to superimpose a parteienstaat on the Framers' handiwork are ill advised. In this Section, I attempt to provide the beginnings of an agency-cost analysis of American political parties. In doing this, I set out and analyze some of the overlooked costs and benefits of American political parties as they might be made to work within the constraints of our political constitutional regime. I conclude by agreeing with Madison (and disagreeing with Edmund Burke) ${ }^{26}$ that while the formation of political parties may be largely inevitable, it is by no means clear that this is altogether a good thing.

\section{CONSTITUTIONAL ORIGINS}

The Framers of our Constitution were quite outspoken in voicing their dislike for "factions" and "parties." James Madison warned eloquently and famously against the "mischiefs of faction" in Federalist 10. And, while conceding that nothing could be done to eliminate the causes of faction since they were "sown in the nature of man," Madison offered a justly celebrated explanation as to how to curtail factions' baneful effects. ${ }^{27}$ The

${ }^{26}$ For a succinct summary of the disagreement between Madison and Burke on the desirability of parties, see id at 24-39. See also Sartori, Parties and party systems at 9-13 (cited in note 21 ).

${ }_{27}$ Federalist 10 (Madison), in The Federalist Papers at 77-84 (cited in note 2). For my own brief analysis and application of the argument of Federalist 10, see Note, $A$ Madisonian Interpretation of the Equal Protection Doctrine, 91 Yale L J 1403 (1982). 
Madisonian solution was to set factions against themselves by so extending the size and sphere of the republic that it would take in a great multiplicity of factions. Madison thus embraced one of his favorite of Voltaire's aphorisms. ${ }^{28}$ That great philosopher had explained England's peaceful politics by saying that:

If there were only one religion in England, one would have to fear despotism; if there were two, they would cut each other's throats; but they have thirty, and they live happy and in peace. ${ }^{29}$

Madison thus so hated and feared factions that he wished for an enormous abundance of them that they might all cancel each other out.

In a similar vein, George Washington issued a famous and also well-remembered warning against factions and parties in his Farewell Address. Given Washington's central and preeminent role in the American Founding, his views on this subject bear quoting at length. He began by warning generally of the dangers of faction and of party, two terms that he, at least, often equated with one another:

I have already intimated to you the danger of parties in the State, with particular reference to the founding of them on geographical discriminations. Let me now take a more comprehensive view, and warn you in the most solemn manner against the baneful effects of the spirit of party generally.

The alternate domination of one faction over another, sharpened by the spirit of revenge natural to party dissension, which in different ages and countries has perpetrated the most horrid enormities, is itself a frightful despotism ....

... [T] of party are sufficient to make it the interest and duty of a wise people to discourage and restrain it.

It serves always to distract the public councils and enfeeble the public administration. It agitates the community with ill-founded jealousies and false alarms; kindles the animosity of one part against another; foments occasionally riot and insurrection. It opens the door to foreign influence

28 Hofstadter, Party System at 61 (cited in note 21).

20 Id, quoting Voltaire's Lettres Philosophiques. 
and corruption, which find a facilitated access to the government itself through the channels of party passion. Thus the policy and the will of one country are subjected to the policy and will of another. ${ }^{30}$

Washington then went on to consider the possibility, argued for by some, that there might be advantages to political parties in a democratic form of government:

There is an opinion that parties in free countries are useful checks upon the administration of the government, and serve to keep alive the spirit of liberty. This within certain limits is probably true; and in governments of a monarchical cast patriotism may look with indulgence, if not with favor, upon the spirit of party. But in those of the popular character, in governments purely elective, it is a spirit not to be encouraged. From their natural tendency it is certain there will always be enough of that spirit for every salutary purpose; and there being constant danger of excess, the effort ought to be by force of public opinion to mitigate and assuage it. A fire not to be quenched, it demands a uniform vigilance to prevent its bursting into a flame, lest, instead of warming, it should consume. ${ }^{31}$

This conclusion is squarely in keeping with the Madisonian view expressed most famously in Federalist 10. Parties may be inevitable in a democracy, but it is not clear that this is a good thing. Every effort should always be made to dampen partisan rancor and rhetoric lest the "spirit of party" get out of hand and become a consuming fire.

Washington's vehemence on this point seems particularly striking because of his enthusiasm, expressed elsewhere in the Farewell Address, for religious, moral, and educational mediating institutions. Plainly there was something about political parties and factions, as such, that especially worried him. Other mediating institutions, connections, and associations were deemed beneficent, even, in his words, "indispensable." ${ }^{\text {2 }}$ Parties and factions were, however, an inevitable evil greatly to be feared. What explains this difference in attitude? Why were combinations de-

30 Washington, Farewell Address at 218-19 (cited in note 20).

${ }^{31}$ Id at 219.

32 Id at 220. 
signed to influence or restrain government deemed automatically to be baleful, while private combinations were not?

Richard Hofstadter persuasively argues that a great part of the explanation can be found by remembering that American ideas about parties were influenced by:

English experience, and that most Englishmen looked back with relief upon the passing of that long, convulsive epoch of English history that occupied the seventeenth century and the first two decades of the eighteenth, in which they saw clear party divisions at work, with consequences they disliked to contemplate. "By 1688," as J.H. Plumb has observed, "violence in politics was an Englishman's birthright." "Conspiracy and rebellion, treason and plot, were a part of the history and experience of at least three generations of Englishmen." Impeachment or attainder, exile or death had at times been the penalties paid by the losers; and the opposition of the 1640's was, of course, associated with a most violent outcome. Party was associated with painfully deep and unbridgeable differences in national politics, with religious bigotry and clerical animus, with treason and the threat of foreign invasion, with instability and dangers to liberty. ${ }^{33}$

In sum, the idea of parties conjured up for the Framers a political world in which the "parts" of the nation were literally at war with one another and with the interests of the "whole." The memory of the English struggle between religious and feudal classbased factions and parties must have left Washington and Madison in fear of something not unlike what we see unfolding today in Bosnia. The idea of parties must have seemed about as scary as anything they could have imagined.

The later history of parties in eighteenth-century England, and during the same period in the American colonies, would have offered no greater encouragement to advocates of party government. Colonial Americans were united in their violent distaste for what they thought was the extreme corruption and venality of eighteenth-century English politics. The desire to escape Englishstyle corruption contributed to the drive for Independence, and it was linked in the popular imagination with the various corrupt cabals and "juntos" that swirled around the so-called English 
Court Party and the Country Party. ${ }^{34}$ Nothing in the more recent English practice with respect to parties and factions would have endeared Washington, Madison, or others of the Founding Generation to the idea of factions or parties. Again, the reality was one of corruption, at best, and intrigue, at worst.

The net result is that by 1789 there were roughly three widely held views about the desirability of parties, only two of which found expression in the United States. ${ }^{35}$ The first view, which Hofstadter calls the Hamiltonian view, was that "parties are evils that can be avoided or abolished or suppressed, even if this must be done, paradoxically, through the temporary agency of a party of national unification." ${ }^{36}$ The second view, which Hofstadter calls the Madisonian view, was that "though parties are indeed evil, their existence is an inevitable by-product of a free state, and that they must therefore be endured with patience by all men who esteem liberty." And, finally, the third view, "identified with Burke in England," but not consistently with anyone in America, was "that parties are not only inevitable but necessary and, on balance, good."38

Because the Burkean view never found any adherents in America at the time of the Founding, Hofstadter concludes that the Constitution was written and put into practice during an era when eliminating the effects of party and of faction was the highest goal. No one during the Founding era voiced anything like a desire for a "party-based state" because no one had any living memory of anything good that had ever come from "parties." To the contrary, history, practice, and the eighteenth-century political science that had resulted all suggested that parties were to be feared and suppressed. The most enthusiasm that could be mustered for parties was, accordingly, the Madisonian view that they were probably an inevitable source of trouble that a wisely constructed republic should seek to discourage through its constitutional structure. As we shall see in Section II, Madison and his

34 Id at $40-49$.

35 Id at 16. at 16.

${ }^{36}$ Id at 16-17. In England, this view was "identified especially with Bolingbroke." Id

${ }_{37}$ Id at 24. This view in England was associated with Hume, whose writings greatly influenced Madison, including the writing of Federalist 10. Id at 24-25. See also Douglass Adair, "That Politics May Be Reduced to a Science": David Hume, James Madison, and the Tenth Federalist, 20 Huntington Libr Q 343, 355-60 (1957).

38 Hofstadter, Party System at 29 (cited in note 21). 
contemporaries did a far better job of accomplishing that goal than they (or others since) probably appreciated.

Another intellectual impulse of the period of the Founding that contributed to the Framers' preference for a great plurality of parties and forces over the existence of only a few came from the Framers' thoughts on, and experience with, matters of religion. As Hofstadter explains:

Madisonian pluralism owes a great deal to the example of religious toleration and religious liberty that had already been established in eighteenth-century America. The traditions of dissenting Protestantism had made an essential contribution to political pluralism. That fear of arbitrary power which is so marked in American political expression had been shaped to a large degree by the experience men of dissenting sects had had with persecution. Freedom of religion became for them a central example of freedoms in general, and it was hardly accidental that the libertarian writers who meant so much to the colonials so often stemmed from the tradition of religious dissent. ${ }^{39}$

Thus, pluralism in matters of religion led Madison and others to favor pluralism in politics and in the number of parties and factions. This is hardly surprising since the legacy of sixteenth- and seventeenth-century English politics must have caused Madison and others to think of parties and factions as being often-at least in part-religiously based.

When, in one of the most famous passages from Federalist 10, Madison discussed how "[t]he latent causes of faction are [ ] sown in the nature of man," he listed as his very first example the fact that men seem to have a "zeal for different opinions concerning religion. ${ }^{\$ 40}$ Religion as a cause of factionalism is listed ahead of: 1) politics; 2) the ambitions of would-be political leaders; 3) vanity; and even 4) "the most common and durable source of factions [which is] the verious [sic] and unequal distribution of property." "Madison must truly have had a great fear of religious factions and of parties, no doubt stoked by memories of the recent history of the English religious wars. Pluralism and accommodation were the solutions to this in his view, and not the encouragement of parties. The energy of parties, of factions, and

39 Id at 55.

40 Federalist 10 (Madison), in The Federalist Papers at 79 (cited in note 2).

4 Id. 
of ambitious leaders must be turned against one another, lest one part tyrannize the whole.

Perhaps this theme helps explain the puzzle that I began with of Washington's Farewell Address, which endorsed religion, morality, and education while warning strongly against the "spirit of party." Maybe Washington implicitly saw American religion as important for its "connections with private and public felicity." ${ }^{22}$ Unlike Madison in Federalist 10, Washington expressed the most concern in his Farewell Address with geographically based parties and factions, perhaps because of his expressed view that most Americans have "[w]ith slight shades of difference, ... the same religion, manners, habits, and political principles."43 Accordingly, Washington saw religious associations as being desirable in an almost Burkean sense because they were "great pillars of human happiness" and of "popular government" when they did not enlist state power into controversial matters. ${ }^{44}$

This then brings me to a final background point that I want to emphasize about political parties as mediating institutions, a point which must be essential to an article like mine, appearing as it does in a Special Issue devoted to the study of mediating institutions in general. And that is that in any discussion of mediating institutions generally, one must be careful to remain acutely aware of the true nature of the "mediation" that is really going on, because not all entities commonly called "mediating institutions" can be truly considered the same kind of beast. Some so-called mediating institutions may truly mediate between the private individual and the state. Synagogues, churches, temples, families, and voluntary community and civic associations and groups often fall readily into this category. ${ }^{45}$ Other groups, however, such as political parties, labor unions, bar associations, and other modern-day corporate "guilds" may not. It may often be the case that these kinds of groups do not so much "mediate" between the individual and the state, as that they try actually to enlist the state on their side of some otherwise-private competitive struggle.

42 Washington, Farewell Address at 220 (cited in note 20).

43 Id at 215 .

44 Id at 220 .

45 See Alexis de Tocqueville, 1 Democracy in America 310-34 (Vintage, 1945) (Henry Reeve, trans). 
Thus, a key difference between political parties as "mediating institutions" and religious, educational, or familial associations as "mediating institutions" must be that the former are ordinarily combinations undertaken to obtain government action for some particular purpose, while the latter are ordinarily combinations formed for private purposes, and that only incidentally act as buffers against the state. There is all the difference in the world between these two distinct kinds of combinations. Entities that seek to harness state power, and the monopoly on legal violence that goes with it, are much more dangerous and much more in need of being watched than those that seek to persuade voluntarily and privately. This is just as true of philosophicallybased entities as it is of business entities or, for that matter, religious entities. ${ }^{46}$

Perhaps I should note at this point that obviously religious, familial, and private associational entities can also-like political parties-find themselves involved in the business of trying to enlist state power on their side, instead of living in accommodation with one another and with nonmembers. When that happens, those entities cease to become mediating buffers between the individual and the state and they become in essence formidable combinations in restraint of "trade." Thus, the first and key question one must ask of anything that might be defended as a "mediating institution" is what entities it is mediating among. "Mediation" between a believer and her God, between a religious leader and his congregation, between a child and his parents, and among the members of a religious, political, or familial association is one thing. "Mediation" between one political or religious sect and the state is quite another, especially if the goal is to enlist the state and its monopoly of power on behalf of one side of an essentially sectarian dispute.

American-style religious, familial, and communitarian/associational ${ }^{47}$ "mediating institutions" are not typically of the type that seek, or have sought, to enlist state power on their side, at

${ }^{46}$ For a different perspective on the question of whether the state is distinguished and defined by its monopoly over coercive power (and distinctively dangerous because of it), the reader would do well to consult Meir Dan-Cohen's thoughtful Article in this Special Issue. Professor Dan-Cohen argues that in our society "different institutions perform different roles with regard to both using force and legitimating it . ..." Meir DanCohen, Between Selves and Collectivities: Toward a Jurisprudence of Identity, $61 \mathrm{U}$ Chi L Rev 1213, 1216 (1994).

47 For an insightful modern treatment of residential associations as mediating institutions, see Clayton P. Gillette, Courts, Covenants, and Communities, $61 \mathrm{U}$ Chi L Rev 1375 (1994). 
least when we compare them with similar associations in Western Europe or in other parts of the world. Political parties and factions, however, exist for no other purpose. The whole goal of such "combinations and associations" is to:

[P] ut in the place of the delegated will of the nation the will of a party, often a small but artful and enterprising minority of the community, and, according to the alternate triumphs of different parties, to make the public administration the mirror of the ill-concerted and incongruous projects of faction rather than the organ of consistent and wholesome plans, digested by common counsels and modified by mutual interests. ${ }^{48}$

The raison d'etre of a "party" or a "faction" is rarely to serve as a buffer between the individual and the state. Far more often, parties and factions exist to co-opt state power and turn it to private advantage. Parties and factions may be largely defeated in doing this by the constitutional structure-in that, Madison has been proven right. But we should not lose sight of the reasons and goals for which political parties and factions are formed. Rarely, if ever, do those goals reflect the desire merely to act as a shield against state power; instead, the goal is usually to co-opt state power for private purposes and to use it against others as a sword.

I think the Framers, Washington and Madison included, were intuitively aware of this distinction among good and bad kinds of mediating institutions. Their condemnation of parties and factions, then, stemmed from their concern with any combination that tries to seize state power in the absence of a broad consensus, and to use that power self-interestedly against other private rivals. Where religion, morality, and education were essentially private undertakings with good, indirect consequences for the wholesomeness of the citizenry, they were worthy of Washington's highest praise. Where religious factions were being viewed as essentially private efforts to subvert the public power of the state, they elicited Madison's stern condemnation. The key question with religious or other factional or party-based combinations would have been, and must be, with whether they are targeted at the harnessing of state power. ${ }^{49}$ With party-based com-

48 Washington, Farewell Address at 218 (cited in note 20).

49 But see Meir Dan-Cohen; $61 \mathrm{U}$ Chi L Rev at 1216 (cited in note 46) (arguing that the state's monopoly over coercion is not as fearsome as imagined). 
binations, it is hard to imagine them as being targeted at anything else.

Now, a "communitarian" or "Democratic-Socialist" criticism that might be made of my analysis up to this point would call into question my implicit endorsement of the public/private distinction. ${ }^{50}$ Put another way, my statement that associations that seek to trigger government action are more suspect than those that seek merely to create a buffer against government action depends on a built-in notion that the private-law distribution of rights is presumptively legitimate. ${ }^{51}$ And, maybe it has built into it as well an extreme (some would say excessive) distrust of exercises of the state's legitimate monopoly on the use of force as compared to exercises of private combinations of economic or social power.

The criticism is a fair one to which I would offer two responses. First, I think the American tradition of at least the Founding Era in on my side on this point. The individuals who wrote our Constitution, and who shaped the early practice under it, had largely the same understanding of the circumstances under which mediating institutions are desirable as the one I have advanced here. This attitude did not begin to alter until at least the time of the initial development of mass political parties under Andrew Jackson. ${ }^{52}$ Thus, anyone seeking to understand

so It has been rightly said that it was Lenin who "laid down the orthodox socialist view when he wrote, "All law is public law." See Mary Ann Glendon, Michael Wallace Gordon, and Christopher Osakwe, Comparative Legal Traditions 266 (West, 1985). There are certainly no "Leninists" around any more and not many pure "Marxists" either. Democratic-Socialism, however, is alive and well, and one of its creeds is a continuing skepticism of the public/private distinction. Many communitarians on the Right and on the Left may share this skepticism to some degree, as well, for different reasons.

${ }^{51}$ But consider the highly thought-provoking article by Cass R. Sunstein, Lochner's Legacy, 87 Colum L Rev 873 (1987), criticizing the phenomenon of "Lochnerism" generally because:

For the Lochner Court, neutrality, understood in a particular way, was a constitutional requirement.... Governmental intervention was constitutionally troublesome, whereas inaction was not; and both neutrality and inaction were defined as respect for the behavior of private actors pursuant to the common law, in light of the existing distribution of wealth and entitlements. Whether there was a departure from the requirement of neutrality, in short, depended on whether the government had altered the common law distribution of entitlements.

Id at 874. I suspect, based on my understanding of Professor Sunstein's views, that he might similarly think that I am guilty of importing "Lochnerian" thinking into this Article's analysis of "mediating institutions."

${ }^{62}$ Hofstadter, Party System at 236-38 (cited in note 21). Mass political parties emerged in the Jacksonian era as the electorate expanded to include many previously disenfranchised voters. Mass political parties thus grew up to mediate between the new, 
the ways in which our Constitution ${ }^{53}$ bears on the problem of parties and of mediating institutions ${ }^{54}$ should accept my understanding of the way in which the public/private distinction bears on this problem. Any other understanding obscures appreciation of the present-day constitutional system.

Second, and more fundamentally, however, I would assert that the Framers were right to view the state, and those who would co-opt it, with the gravest suspicion. The history of the various totalitarian movements of this century bears them out. ${ }^{55}$ Those who would erase (or blur) the public/private distinction overlook the many horrors that total government power can yield when there is no private sphere to buffer or "mediate" its force. Government power, unlike private power, grows largely from the barrel of a gun. ${ }^{56}$ Private power grows largely from people's voluntary desire to associate with and do business with one another.

vast mass party in the electorate and its small governing coterie, the party in Congress and in the White House. For Alexis de Tocqueville's views on political parties in the United States during the Jacksonian era, see Tocqueville, Democracy in America at 17480, 194-95 (cited in note 45). For an analysis of Tocqueville's understanding of political parties, see Wilson Carey McWilliams, Tocqueville and Responsible Parties: Individual. ism, Partisanship, and Citizenship in America 190 (Southern Mlinois, 1992).

E3 By the Constitution, I mean here the original written document of 1787, as amended, as it was originally understood. I am not referring to an evolving, British-style customary set of traditional constitutional practices. But see generally Bruce Ackerman, We the People 1: Foundations (Belknap, 1991) (arguing brilliantly, but wrongly, for essentially just such an understanding of the American "Constitution").

54 Professor Akhil Amar has pointed out to me that the Framing Generation took a major step toward accomodation of political parties when the Twelfth Amendment was ratified in 1804. But this sole accomodation of the reality of the existence of parties does not undercut my point that the vast bulk of our Constitution was designed to discourage parties and not to accomodate them. Indeed, as Professor Amar has pointed out in a brilliant article, the Twelfth Amendment merely permits, but does not require, partyticket voting for the Presidency and the Vice Presidency. Akhil Reed Amar and Vik Amar, President Quayle?, 78 Va L Rev 913 (1992).

${ }^{65}$ For a nice summary of the evils that statism has led to in this century, the interested reader could do no better than to consult Paul Johnson, Modern Times: The World From the Twenties to the Eighties (Harper \& Row, 1983). For a description of the lives of people who contributed to making the twentieth century all that it has been, see Paul Johnson, Intellectuals (Harper \& Row, 1988).

${ }^{56}$ Obviously, there is a sense in which private economic power depends on government "force" to protect property rights. Obviously, there is also a sense in which government power grows out of social consent and not merely from the exercise of force. The fact remains, however, that private transactions rarely involve or require invoking the state's coercive machinery, while few governmental undertakings could be long sustained if participation in them were voluntary. Marxism notwithstanding, it is the claims of the State which rest on the power of the threat of violence and not the claims of the private sector. Perhaps, it is the widespread and growing recognition of this basic truth that helps to explain the speedy demise that seems to be everywhere occurring of Marxism and, most especially, its Leninist mutation. 
There can be little doubt as to the relative risk and desirability of these two kinds of power, which is why the liberal, Western philosophic tradition, broadly defined, has always accepted the inevitable desirability of a public/private distinction. The nature and proper boundaries of the distinction may, at times, be questioned. And for the record, I should probably concede that I have a particularly "privatist" understanding of where the lines should be drawn relative to more generally accepted views. But nonetheless, the distinction itself-and therefore its implications for "mediating institutions"-must be seen as largely a given in our legal, political, and philosophical culture. The burden on this point must surely lie with those who would dispute me, and not on myself.

A final background question that one might wish to ask about the Framers' views on such mediating institutions as religious associations and "parties" would concern the extent to which they believed such entities promote civic virtue. Thus, a civic republican ${ }^{57}$ might wonder what effect the Framers thought such associations would have on the personalities of the people participating in them. Could it be that by turning people's attention to civic, communitarian concerns, certain kinds of associations, including parties, would promote virtue? Or was it the Framers' view that the promotion and inculcation of virtue would occur wholly in privately-based religious and community organizations?

In this regard, I think it is telling that Washington warns in his Farewell Address against "the spirit of party" that "unfortunately, is inseparable from our nature, having its root in the strongest passions of the human mind." ${ }^{\text {I }}$ I think the concern here is obviously not only with the ill effects of parties on government, but also with their bad effects on the morals of those individuals who choose to participate in them-on those who, as Tolkien would later put it, choose to wear "the ring of power" and then cannot give it up when the time comes. ${ }^{59}$ Public mindedness, a concern with the needs of the citizenry as a whole, was a quality widely praised at the time of the Framing as the civic republican literature documents well. ${ }^{60}$ But, this civic virtue was not

${ }^{57}$ For an introduction to the civic republican literature, the reader might consult Cass R. Sunstein, Beyond the Republican Revival, 97 Yale L J 1539 (1988); Frank Michelman, Law's Republic, 97 Yale L J 1493 (1988); Richard H. Fallon, Jr., What is Republicanism, and is it Worth Reviving?, 102 Harv L Rev 1695 (1989).

s8 Washington, Farewell Address at 218 (cited in note 20) (emphasis added).

59 J.R.R. Tolkien, The Fellowship of the Ring 59-71 (Houghton Miffin, 2d ed 1965).

${ }^{60}$ See, for example, Federalist 10 (Madison), in The Federalist Papers at 80 (cited in 
seen as being enhanced by participation in factions or in what we would think of as political parties. Rather, the opposite was the case. The "spirit of party" or the "mischief of faction" was most likely seen not as something that was publicly minded but as something that was divisive. The essence of the "spirit of party" was that it sought to co-opt the government of the whole people for the benefit of a few.

In sum, much of the relevant history and background to America's constitutional understanding of parties as mediating institutions suggests a great deal of justified suspicion toward them. This in turn resulted in a constitutional structure that, to Lloyd Cutler's dismay, makes party government even harder to implement than is commonly realized. Without realizing or intending to do so, the Framers wrote a Constitution that absolutely forecloses the possibility of parliamentary English-style party government in this country. ${ }^{61}$

\section{II. "A Constitution AgAinst PARTies"}

I now wish to examine three aspects of our constitutional structure that are frequently overlooked and that make government by modern mass political parties very difficult to realize in this country. First, I wish to examine the ways in which (and the degree to which) our constitutional system of separation of powers, in fact, makes it difficult to set up party-based government. My thesis here is that the obstacles that are created are much

note 2 ).

61 The Framers, of course, were totally unfamiliar with benign party government of the parliamentary kind, since that governmental form did not appear in human history until the early to middle nineteenth century in England. Thus, the Framers' "Constitution Against Parties" was not constructed to foreclose Cutlerian English-style parliamentary government. Rather, it was constructed to foreclose government by cabal ("the English Court party"), government by a fanatical mass religious movement (Cromwells, Roundheads), and government by and for special interests (the Madisonian "faction"). I do not mean to suggest that modern, democratic mass political parties, of the kind that have existed in this country since the Jacksonian Era, are just as reprehensible as their seventeenth- and eighteenth-century English and American forbearers. Nor do I mean similarly to condemn modern parliamentary democracy as it functions in the United Kingdom. I do mean to suggest that some of the Framers' fears of political parties, particularly untamed political parties, were justified and rooted in experience. Moreover, drawing on these fears, the Framers constructed a constitutional system that makes all kinds of party government far more difficult than is commonly realized. Finally, I would suggest that the Framers' bad memories of the untamed political parties of their day should not be forgotten by American anglophiles who wrongly assume that most of the world's political parties are tame and well-behaved like our Democrats and Republicans. They are not. I suspect that the Anglo-American expreience of 1640 to 1800 remains very relevant as a reminder of the mischief and evil that parties are capable of committing. 
more formidable than is commonly understood. Second, I wish to examine some easily overlooked aspects of the powerfully centrifugal, geographical forces that are unleashed by the biases created by our electoral system. Here again, I think we can find a hidden key to why party government is so difficult under our constitutional regime. And, third and finally, I wish to focus on the ways in which the heterogeneity and geographical size of the country affect the American party system. These factors, in my judgment, both complicate the task of those who advocate party government and make the spectre of such government less fearsome than it otherwise would be.

\section{A. Separation of Powers and of Personnel}

First, it is generally acknowledged by all sides of the current debate over the reforms proposed by Lloyd Cutler's Committee on the Constitutional System ("CCS") that there exists a tension between our constitutional system of separation of powers, ${ }^{62}$ on the one hand, and the supposed ideal of "party government," on the other. As matters are usually put, party government is in tension with separation of powers because it seeks to bring "together under informal arrangements what the founders were at pains to divide by formal ones. ${ }^{263}$ Many writers who favor party government assume, as Cutler states explicitly, that the division to be bridged is "the basic separation of executive and legislative powers." ${ }^{\text {"4 }}$ The assumption is that party-based government would simply bridge a gap between the executive and legislative

62 For a fascinating discussion of how separation-of-powers principles can illuminate another area of law, see Ira C. Lupu, The Separation of Powers and the Protection of Children, $61 \mathrm{U}$ Chi L Rev 1317 (1994).

63 Wilson, Political Parties at 18 (cited in note 3).

at Cutler, To Form a Government at 13 (cited in note 11). As Cutler puts it, what he hopes for "is a set of modest changes that would make our structure work somewhat more in the manner of a parliamentary system, with somewhat less separation between the executive and the legislature than now exists." Id. 
"branches"65 or institutions of the government. The reality, however, is far more complex.

In a forthcoming article with Joan Larsen, ${ }^{66} \mathrm{I}$ explain that our constitutional system began as a system of constitutionally separated powers ${ }^{67}$ but has evolved into something that is really quite different. The most politically important reality today may be not so much that we have a separation of powers or even that we have a separation of institutions (or "branches"). Rather, the politically most important reality today is that we have gone beyond all of that to a radically decentralized system of separation of personnel. Put another way, what is striking about our government today is not that its legislative and executive powers are separated or that we have three "branches" to our government. Rather, what is striking is that we have developed a series of incompatibility rules that make it impossible for the same individual ever to serve simultaneously in more than one office.

Thus power is divided not so much into three types (legislative, executive, and judicial) or among three "branches" (Congress, the executive, and the courts). Rather, power is divided

${ }_{65}^{65}$ In a previous article, I explained why, in my judgment, it would make more sense for us to refer to the three institutions of our national government as "departments" rather than as "branches." See Calabresi and Rhodes, 105 Harv L Rev at 1156 n 6 (cited in note 1). I continue to believe that is the case, particularly in the context of a legal, textual argument. For purposes of this Article, which addresses a nonlegal, policy problem with overtones of political science, I will use the term "branch" to avoid creating unnecessary confusion. To indicate my continuing protest against the use of this word, however, I will put quotation marks around it whenever I use it herein. For those who are wondering why I could possibly care about this, and who do not want to look up footnote 6 of my article with Kevin Rhodes, the short answer is that the word "department" conveys hierarchy in a way that the word "branch" does not. Departments are typically structured like pyramids. Thus, as an advocate of Executive hierarchy, I prefer the term "Executive Department" to the term "Executive Branch" because of the connotation that is created, thereby, of presidential control. Since the Constitution actually uses the term "Department" instead of the term "Branch" in referring to the three main institutions of our national government, I advocate a return to our early historical practice of calling those institutions by their rightful "departmentalist" name.

${ }_{66}$ Calabresi and Larsen, 79 Cornell $L$ Rev (cited in note 11).

67 Strictly speaking, as many have pointed out, the constitutional text creates a regime of constitutionally separated and shared powers, since many of the three traditional powers of government are divided up among the Congress and the executive, at least, to create a structure of checks and balances rather than one of airtight separation. See Federalist 51 (Madison), in The Federalist Papers at 301-03 (cited in note 2). Thus, the President shares in the legislative power through his veto, the Senate shares in the executive power through its right to confirm nominees, and the House of Representatives shares in the judicial power through its sole power to bring bills of impeachment. Thus, Cutler is able to say with some justice that "[t]he followers of Montesquieu at the Philadelphia Convention at best won half a Loaf." Cutler, 18 Pres Stud Q at 485 (cited in note 11). 
among thousands and thousands of office holders, no single one of whom can hold more than one office at the same time. Numerous incompatibility rules (some constitutional and others not) create an elaborate system of separation of personnel, not only among the three "branches" of the federal government and between the federal government and the states, but also within each of the three "branches" of the federal government as well.

Thus, the Incompatibility Clause of Article I, Section 6 of the Constitution precludes Members of Congress ("MCs") from jointly holding executive or judicial office. ${ }^{68}$ The Incompatibility Clauses of forty-seven out of fifty state constitutions specifically preclude federal officers from jointly holding at least some, if not most, significant state offices: ${ }^{69}$ And an unwritten, but hallowed, incompatibility tradition (at least today ${ }^{70}$ ) precludes federal judges from simultaneously holding most executive offices. ${ }^{71} \mathrm{Plu}$ ral office holding among the three "branches" and between the federal government and the states is thus almost totally foreclosed.

But to acknowledge this is only to begin the task of describing the full universe of legal rules we have developed that create incompatibilities. To fully appreciate our intricate system of separation of personnel, one must also look at the incompatibility rules that exist within each of the three (or is it four ${ }^{72}$ ) traditional "branches." The President's executive "branch" is carved up, by statute, into numerous different cabinet departments, agencies, subcabinet positions, commissions, boards, and other entities. Duties and statutory powers are frequently assigned, by law, to named office positions within this vast hierarchy, and it has been long accepted that such statutory assignments preclude the President from directly taking those actions that Congress

69 US Const, Art I, § 6, cl 2 ("[N]o person holding any office under the United States, shall be a member of either House during his continuance in office."). Lloyd Cutler is acutely aware of at least this incompatibility rule, since he wants to follow Woodrow Wilson's advice and amend the Constitution to repeal it. See Cutler, To Form a Government at 13-14 (cited in note 11).

69 See Calabresi and Larsen, 79 Cornell L Rev (cited in note 11) (collecting state constitutional citations and discussing the significance of these incompatibility rules).

70 A different situation prevailed during the very early years of our constitutional history. See generally Russell Wheeler, Extrajudicial Activities of the Early Supreme Court, 1973 S Ct Rev 123.

${ }^{7}$ See also Model Code of Judicial Conduct 28-32 (Canon 5) (ABA, 1990) (purporting to regulate the extent to which joint executive-judicial service is acceptable).

${ }_{72}$ Compare Lawrence Lessig and Cass R. Sunstein, The President and the Administration, 94 Colum L Rev 1, 38-70 (1994), with Steven G. Calabresi and Saikrishna B. Prakash, The Executive's Power to Execute the Laws, 104 Yale L J (forthcoming Nov 1994). 
has specified to be the province of one of his subordinates. ${ }^{73}$ Moreover, a combination of federal statutory bans on dual office holding, of federal conflict-of-interest rules, and of traditions (that would be enforced through the Senate confirmation process) completely precludes the plural holding of most, if not all, executive offices. Occasionally, someone like Roger Altman manages nonetheless to serve simultaneously as a Deputy Treasury Secretary and as an Acting Head of the Resolution Trust Corporation ("RTC"); but, as Mr. Altman discovered, Congress generally finds ways to render this state of affairs short lived. Plural office holding in the federal executive is, effectively, illegal, even as it is unconstitutional in many states as a matter of state constitutional law. ${ }^{74}$

An analogous situation exists within the federal legislature and judiciary. Congressional party caucus rules carefully divide the number of committee and subcommittee slots, positions that are functionally the equivalent of offices, allocating only a certain number of major and minor slots to each member of the majority and minority parties. ${ }^{75}$ In addition, congressional rules specify how many committee or subcommittee chairmanships each member can hold. ${ }^{76}$ Within the judiciary, the rules are only slightly less rigid. By statute and tradition, judges of the district, circuit, and supreme courts, on occasion, sit by designation on a federal court other than the one to which they were appointed and for which they are commissioned..$^{77}$ But, by and large, in the normal course of things, judges are appointed to and hold only one judicial office at a time. There is no history of, or precedent for, federal judges holding multiple judgeships at the same time.

To return to my main point then, the reality of our constitutional system is not so much that it creates a trinitarian separation of powers or of "branches," but that it creates almost a millenarian separation of personnel. Tens of thousands of political officers, and millions of civil servants, are constituted by stat-

${ }^{73}$ See Gary Lawson, The Rise and Rise of the Administrative State, 107 Harv L Rev $1231,1242-43$ (1994).

${ }_{74}$ This illustrates the depth of the American aversion to plural office holding. See Calabresi and Larsen, 79 Cornell L Rev (cited in note 11).

75 See Rules 18 \& 19, Preamble and Rules of the Democratic Caucus 6-7, 103d Cong (Jan 11, 1993); Rule 12, The Rules of the Republican Conference of the United States House of Representatives, 103d Cong.

${ }_{76}$ Rule 21, Rules of the Democratic Caucus at 7; Rule 15, Rules of the Republican Conference.

77 See, for example, 28 USC $\$ 331$ (1988) ("The Conference . . . shall prepare plans for assignment of judges to or from circuits or districts where necessary."). 
ute and tradition as semiautonomous entities in separate fiefdoms, no two of which can be jointly held.

Now the immediate response that will occur to the reader is to say that these so-called fiefdoms of multiple offices are not really autonomous at all, because the Constitution puts the President in charge of almost all of them since they happen, of course, to be in the Executive "branch." Well, unfortunately, in my view that is true only in the most tenuous way. The President has no legal authority to act in the stead of his subordinates, only limited legal authority (or political power) to fire them, and maybe, at most, some legal power to nullify actions taken in his name that he is lucky enough even to hear about. ${ }^{78}$ Thus, although it pains me to say it, I do not think it is true today that the President is really in charge of the officialdom of the Executive "branch" in any very meaningful sense, even though he ought to be if either the Constitution or common sense prevailed. ${ }^{79}$

Similarly, no officer or officers in the legislative or judicial "branches" can really be said to be in charge of the multiple offices that exist within those "branches." Neither the Speaker of the House of Representatives, nor the Majority Leaders of either the House or the Senate, can be said to be truly in charge of the legislative committee "officeholders" in any very meaningful way. Since the revolution against former House Speaker Joseph G. Cannon, party discipline in Congress has been minimal at best, and the trend in the last twenty years is toward even more democratization of party caucuses. ${ }^{80}$ Within the judiciary, the Chief Justice presides over the Judicial Conference of the United States, ${ }^{81}$ and the Supreme Court sits atop what Gary Lawson and I have argued is a judicial hierarchy, ${ }^{82}$ but the reality is that the judicial hierarchy is an intentionally decentralized

78 Lawson, 107 Harv $\mathrm{L}$ Rev at 1242-44 (cited in note 73).

79 For a normative defense of this argument, see Steven G. Calabresi, Some Normative Arguments for the Unitary Executive, 47 Ark L Rev (forthcoming Fall 1994). For a constitutional defense, see Calabresi and Rhodes, 105 Harv L Rev at 1153 (cited in note 1); Steven G. Calabresi, The Vesting Clauses as Power Grants, $88 \mathrm{Nw}$ U L Rev 1377 (1994); Calabresi and Prakash, 104 Yale L J (cited in note 72). For a constitutional and normative analysis of the problem, with a focus on independent agencies, see Geoffrey $P$. Miller, Independent Agencies, 1986 S Ct Rev 41.

${ }^{80}$ See Wilson, Political Parties at 19-26 (cited in note 3); Sundquist, Constitutional Reform at 258-60 (cited in note 6).

8128 USC § 331.

82 Steven G. Calabresi and Gary Lawson, Equity and Hierarchy: Reflections on the Harris Execution, 102 Yale L J 255, 272-79 (1992). 
one. ${ }^{83}$ Accordingly, there is no more, and may be less, hierarchy within the federal judicial system than there is within the federal legislature or executive. The decentralization caused by our constitutional regime of separation of personnel exists unimpeded by concerns of hierarchy in all three of the "branches" of the federal government.

If, then, it is correct to say that American-style separation of powers is really a system of separation of personnel, what significance does this fact hold for the idea of party government? Why does it matter in assessing Lloyd Cutler's proposals that we have a far more fragmented governmental system than the phrase "separation of powers" tends to convey?

The answer is that it is much, much harder to bring "together under informal [party] arrangements"84 tens of thousands of quasi-independent officers than it is to bring together two hierarchically organized "branches," the one headed up by a powerful unitary President and the other headed up by powerful legislative leaders, in the mold of former House Speaker Cannon or former Senate Majority Leader Lyndon Johnson. In other words, the American government is plagued by far worse "divisions" and "separations" of power than the simple constitutional division between the executive and legislative "branches." Before one even gets to worrying about the constitutional division, one must face the enormous erosion in hierarchy that has occurred within the legislative, the executive, and maybe even the judicial "branches."

This erosion of hierarchy, fostered by our system of separation of personnel, makes the notion of true English-style party government very unlikely in this country, even if we were to adopt Cutler's proposed reforms. First, as Joan Larsen and I have observed, ${ }^{85}$ Cutler's reforms would at best produce a partial fusion of the congressional committee structure and of some of the cabinet departments. ${ }^{86}$ And it would only accomplish that because, as Woodrow Wilson realized long ago, the congressional committees are, to a significant degree, shadow (parliamentary) executive organs that have grown up in this country to influence the execution and administration of the laws. The congressional committee structure is this country's stunted growth of a fused

83 Id.

4 Wilson, Political Parties at 18 (cited in note 3).

85 Calabresi and Larsen, 79 Cornell L Rev (cited in note 11).

(U) Under the Cutler proposal, the fusion would be very partial indeed, because only $50 \%$ of the cabinet slots would go to MCs. Cutler, To Form a Government at 13-14 (cited in note 11). 
legislative/executive parliamentary government. The main thing that keeps the committees from becoming such a full-fledged parliamentary government is the fact that the Incompatibility Clause prevents the Committee and Subcommittee Chairs from seizing the Cabinet Secretary and Assistant Secretary slots that the committees and subcommittees "oversee."

The partial fusion of the congressional committee structure with some of the cabinet departments that Cutler's proposal would create would not affect the system of separated personnel that I describe above. At best, it would change our present government structure, making a few of the leading barons of Capital Hill-say Sam Nunn, Dan Rostenkowski, Patrick Moynihan, and John Dingell-even more powerful than they are now. The Cutler proposal would not necessarily create more hierarchy either within Congress or within the Executive "branch." And, it is only by creating more hierarchy that the highly decentralized system of separation of personnel can be brought under control. While party accountability obtained through ballots specifying partyticket voting may sound great in theory, it can only work if the parties are hierarchically structured so that party leaders can exert discipline and control, as they do in Britain. ${ }^{88}$ Accomplishing this requires not only leadership control over the nomination process-as James Q. Wilson has argued ${ }^{89}$-but also party-leadership control over tenure in executive office, over committee assignments, and over the structure of what can be debated for how long and when on the Senate and House Floors. Currently, there

87 The situation is complicated by the fact that one could fairly question whether, absent the Incompatibility Clause, Congress's political leverage against the President would be great enough for it to be able to wrest the whole of the cabinet away from the President's men. Perhaps, when all was said and done, Congress would get only half or even a quarter of the cabinet. Different people with whom I have discussed this come up with different guesses, and, unless we try Cutler's "experiment," we will never know for sure. My own guess, for what it is worth, based on my limited experience working in Washington, is that Congress would succeed in taking over a lot more than most people think. Congress has so much more power under the Constitution than does the President that, in practice, I think the President would end up having to trade most of the prestigious "Offices" theoretically at his disposal to committee chairs in order to get any of his legislative program passed.

${ }_{88}$ But see Sundquist, Constitutional Reform at 276-77 (cited in note 6). Sundquist argues that the primary problem with the American system is divided government and not the lack of party hierarchy. Sundquist argues that we must have unified government before party unity becomes decisive. See id. However, this may simply be a chicken-orthe-egg problem. Sundquist sees both unified government and strengthened party hierarchy as essential to restoring effective and accountable government. See id at 125-31 (team-ticket proposal), 245-74 (proposals for strengthening political parties).

89 Wilson, Political Parties at 26 (cited in note 3). 
is simply no one in the U.S. Government-not the President, not the Speaker of the House, not the Senate Majority Leader-who has that kind of power. I don't see anything in Cutler's proposal that changes this. If anything, I think his proposed partial repeal of the Incompatibility Clause will make matters worse.

To see why that is the case, consider what the U.S. Government would be like today if 50\% of President Clinton's cabinet included powerful Committee Chair MCs. The shadow-parliamentary committee structure would be greatly strengthened. This in itself would be a bad thing because the committee structure is already a source of "pork-barrel" trouble in our government: it tends to take national resources and money and funnel them back to local, geographically based electoral constituencies. ${ }^{90}$ But, even leaving that very serious problem aside, the Cutler proposal would tend to weaken the President's control of the executive "branch" without giving that control instead to some kind of new hybrid legislative/executive officer like the Prime Minister of Great Britain. Put another way, the Cutler proposal would weaken the presidency without killing it off: no true prime-ministerial system would be substituted for the system we have now. ${ }^{91}$

This seems to me to be the worst of all possible worlds. Cutlerism would weaken the presidency without setting up a workable parliamentary regime in its place. A weakened President, with his own national electoral mandate, would preside over a cabinet headed up by a congressionally elected Prime Minister whom he could not fire! As a result, we would get neither the accountability that characterizes the British system, nor the separation of the Committee Chairs from the "pork" they oversee that characterizes the American system. In place of either system, we would have a national government administered by Committee Chairmen/Cabinet Secretaries whose reelection to Congress depends on their ability to please small state and local, geographically based, electoral districts. Such a system strikes me as highly likely to lead to gross ethical abuses. Conflicts of interest between the obligations of the hybrid Committee Chairmen/Cabinet Secretaries to the nation and to "the folks back home" would exist everywhere. ${ }^{92}$ The country would find the same pork-barrel politics that now characterize the congressio-

50 For more detailed discussions of this point, see Calabresi and Larsen, 79 Cornell L Rev (cited in note 11); Calabresi, 47 Ark L Rev (cited in note 79).

91 See Calabresi and Larsen, 79 Cornell $L$ Rev (cited in note 11).

92 Id. 
nal-appropriations process spreading into all areas of the administration and execution of federal law.

Now one objection that might be raised to my analysis thus far is to question how it is that other Western democracies maintain an extensive set of incompatibility rules (and thus an elaborate separation of personnel) while also preserving something akin to "party government." Germany, in particular, could be said to have both a parteienstaat and a separation of powers that is also largely a separation of personnel. ${ }^{93}$ To some degree the same thing may be true of the United Kingdom as well, which combines a system of hierarchical party-based government with at least a highly professionalized, nonpartisan civil service.

The answer is complex, but I think a number of factors help explain the difference. First, there may be a greater tradition of the nonpartisan civil service following the orders of the ministerial hierarchy in some foreign countries than there is in the United States. This is not to say that bureaucracies everywhere do not engage in foot dragging. But I do wonder whether our American civil servants may accept guidance from above less readily than their European counterparts, perhaps partly for cultural reasons and partly out of a need to please two masters: the Cabinet Secretary and the Committee Chairman. No similar constraint exists to make miserable the life of the European civil servant.

Second, the sheer size of our federal system, both because of our land mass and our population (and because, unlike Germany, we have fifty state governments), means that the separation of personnel here is and must be more daunting than it is in Bonn. An American political party that would bridge that separation-ofpersonnel gap must link together many more political office holders than would a comparable German political party. Accordingly, the costs of gap bridging are much higher here than there, and the likelihood of success is much lower. And that is even before we take into account the fact that the American political culture, with its emphasis on democratization and decentralization, may be particularly hostile to partisan/hierarchical gap-bridging endeavors! When we factor in, as well, the fact that we have much more developed, separate legislative committee structures, with much larger staffs, the explanation becomes clearer. There are

${ }^{83}$ For a superb discussion of separation of powers in Germany, see David P. Currie, Separation of Powers in the Federal Republic of Germany, 41 Am J Comp L 201 (1993). See also Kommers, The Constitutional Jurisprudence of the Federal Republic of Germany at 121-69 (cited in note 17). 
many, many differences, then, between the United States, on the one hand, and Germany and England, on the other, that explain why political parties are unlikely to bridge the separation of personnel here even though they succeed in doing so there. The American legal structure of separation of personnel, which is partly constitutional, partly statutory, and partly tradition based, is very unlikely to be bridged any time soon by "party-based government." The adoption of Lloyd Cutler's proposals would not so much change this as make other-already problematic-features of our governmental system worse.

In sum, when Cutler and others talk about how political parties might be used to "bridge the separation-of-powers gap between the executive and legislative 'branches' of the government," they are obscuring a far more complicated and daunting reality. Our legal regime is as much one of separated personnel as it is one of separated powers or "branches" and no Americanstyle political party is ever going to be hierarchical enough and powerful enough to bridge the separation-of-personnel gap.

\section{B. The Electoral System}

The second point I wish to examine builds on the discussion thus far and considers how aspects of our geographically-based electoral system greatly complicate the task of those who would create a hybrid legislative/executive party-based government. ${ }^{94}$ Again, there are some who have identified geographical-constituency factors as being important to explaining the lack of party discipline in Congress, ${ }^{95}$ but I think the point is critical enough to merit further attention and analysis.

Inquiry must begin here with a few very basic but fundamental observations. The United States today has a very powerful redistributive Big Government that has evolved over a period of two hundred years into something quite different from what was originally imagined to be likely. That government taxes, borrows, and spends almost 25 percent of the nation's GDP, ${ }^{96}$

04 For a good general discussion of how different electoral structures can affect parties and politics in different countries, see Douglas W. Rae, The Political Consequences of Electoral Laws (Yale, 1967).

${ }_{95}$ See Wilson, Political Parties at 32 (cited in note 3) ("[T]he advantages to congressmen of a decentralized and fragmented Congress are [] great-the fragmentation permits them to pursue their desire for reelection (not their only goal, but obviously an important one) with a minimum of party or presidential constraints.").

${ }_{06}$ In fiscal 1992, the federal government took in $\$ 1.1$ trillion in taxes, ran a deficit of $\$ 290$ billion, and spent a total of $\$ 1.4$ trillion, or 23.5 percent of GDP, on transfer pay- 
and it regulates (or guides state regulation of) a much bigger percentage of the remaining GDP that is not confiscated and redistributed outright. Yet for all the changes that have occurred to permit this to happen, there is one very, very important feature of our constitutional system that has not changed a bit. And that is our geographically-based electoral system for picking Members of Congress. ${ }^{97}$ Today, as in 1789, Senators represent states, Representatives represent single-member geographical districts, and the President represents an electoral-college majority of the nation as a whole. ${ }^{98}$ There has been no evolution of our electoral system comparable to the evolution and growth that has occurred in the scope of our national government's theoretically limited and enumerated powers.

What this means is that over two hundred years of American history the size of the pie that government redistributes has grown enormously, while the incentive structure for pie division has remained precisely the same. ${ }^{99}$ Particularly because of the growth in the spending power, ${ }^{100}$ the Congress today faces essentially the following set of pie-division incentives. An MC concerned with maximizing her potential to be reelected to Congress will want, ideally, to try to tax the nation as a whole, while steering a disproportionate share of the proceeds back to her district. As each MC faces and internalizes this set of incentives, a collective-action problem emerges. ${ }^{101}$

Every MC's highest priority is to prove his ability at bringing visible evidence of national pork back to his district. To do this may require approving ever higher and higher levels of national

ments, purchases of goods and services, and interest payments. Council of Economic Advisers, 1993 Annual Report 244 (US GPO, 1993).

${ }_{97}$ The only formal changes in the system have been the provision for direct election of Senators and the gradual expansion of the suffrage over time to include many previously disenfranchised groups.

98 Some very important aspects of our national electoral structure are matters of state election law and could be changed fairly easily, although they have not been significantly altered as they bear on my analysis here.

99 Further discussion and analysis of this phenomenon can be found in Calabresi, 47 Ark L Rev (cited in note 79).

100 Compare, for example, United States $v$ Butler, 297 US 1, 61 (1936) ("[Tax] has never been thought to connote the expropriation of money from one group for the benefit of another."), with South Dakota $v$ Dole, 483 US 203, 207 (1987) ("[O]bjectives not thought to be within [Article I] ... may nevertheless be attained through the use of the spending power and the conditional grant of federal funds.").

101 I use the term collective-action problem rather than prisoner's dilemma because in a true prisoner's dilemma one player is totally ignorant of the other's acts. This is not always the case in Congress, although sometimes it is. Accordingly, the situations facing MCs should be characterized, more generally, as a set of collective-action problems. 
taxation, borrowing, and spending than many MCs might otherwise want. But, since the highest priority is national-to-local redistribution, that factor ends up driving all other spending and taxing decisions. The higher the percentage of GDP the national government consumes, the more urgent the race becomes. If 50 percent of our income were taxed away nationally, instead of approximately 20 percent, it would be much more than twice as important for our MC to prove his ability to get some of that money back. ${ }^{102}$ Yet, the harder each MC tries to do that, the higher the overall levels of spending, borrowing, and taxation will tend to go.

The iron dynamic of the American electoral system thus creates a grim but clear incentive structure for MCs. Put your district or state ahead of the nation or else! ${ }^{103}$ The very size and breadth of the nation, if anything, make matters even more extreme. With a whole continent to loot, Senator Robert Byrd can bring back a whole lot more for a state like West Virginia than he could if he were only able to loot a medium-sized nation-state like France. The dimensions to which the country has grown thus may even exacerbate the electoral-incentive-structure problem. Congress is a 435-member rapacious army of state and local agents, all of them trying to redistribute from the whole to a part.

The one exception to this electoral-incentive nightmare can be found in the office of the Presidency. The President is electorally responsible to the nation as a whole. He is almost always picked by a majority of the Electoral College, ${ }^{104}$ and he probably thinks of his potential reelectoral constituency as including up to 60 percent of the electorate (the percentage won by presidents of both parties in landslide elections from 1964 to 1984). Moreover, that constituency may well exist in as many as forty or more states (again, the number won in landslide elections by presidents of both parties in recent years). This suggests that the President faces a radically different incentive structure from the incentive structure faced by the average MC. The President must

102 This is because, as voters lose more and more of their income to federal taxes, they experience a greater and greater gain in marginal utility for every "stolen" federal tax dollar that they manage to get back.

${ }^{103}$ For an explanation of why changes to our electoral structure (by moving, for example, to European-style proportional representation) would make matters worse, see Calabresi, 47 Ark L Rev (cited in note 79).

104 Elections rarely go to the House of Representatives, although, of course, it can happen. 
typically try to build a national electoral majority and please it, possibly by disproportionately burdening or taxing some temporarily unpopular national minority (either of a geographical, or a class, or a racial type). The average MC, on the other hand, must do just the opposite. He must try to burden or tax the national majority, while steering the resulting loot back to his district or state.

In sum, the 1787 electoral incentive structure is radically different for presidents and for MCs. This difference has been silently becoming more and more important over the course of American history as the size of the national share of GDP has silently crept up. The bigger the national pie, the more skewed the set of congressional pie-division incentives. And, the more skewed the set of congressional pie-division incentives, the harder the President and his subordinates must fight to protect some national majority coalition from congressional, localist depredations. Severe conflict between the President and the Congress is almost constitutionally guaranteed by this electoral incentive structure, coupled as it is with the evolved redistributive role of post-New Deal big government. The President and the Members of Congress are playing to very different electoral audiences, which want from them very different things. ${ }^{105}$

Well, then, what is the implication of all of this for the advocates of Lloyd Cutler-style party-based government? What is the significance for Cutlerism of the powerfully different incentive structures faced by Presidents and MCs?

The answer, I think, is that it makes the prospect of a successfully fused legislative/executive much less plausible than Cutler seems to believe. The incentives created by the electoral structure are powerfully centrifugal, and their most natural tendency is to rip presidential-congressional ties apart. To create bonds of party that will overcome this would require more "reform" than Cutler has yet proposed.

Now Cutler is not insensitive to the fact that the electoral system must change for his proposal to get anywhere. ${ }^{106}$ To the

105 For purposes of this analysis, I am assuming, as is largely the case, that MCs do not to a significant degree alter their behavior to please the party caucus of the House in which they sit. In recent years, this has changed slightly in the House of Representatives, where Members desiring a committee chairmanship must now to some extent worry about an electoral majority of the House Democratic Caucus, since the seniority system no longer completely holds sway. But, for the overwhelming majority of members, pleasing this electorate is still much less important than pleasing their primary and general election electorates in the district back home.

106 Just as he was not oblivious to at least some (though not all) of the lurking prob- 
contrary, he proposes all sorts of electoral reforms that he thinks would promote party government. Single-party ballots for MCs and Presidents, powers for the President (and Congress) to call special elections, a six-year, nonrenewable presidential term-Cutler proposes all of this, ${ }^{107}$ and all of it would to some extent blunt the current brutally conflictive situation. But at the end of the day, the MCs would be left running in single-member districts and in the states, while the president would still run nationwide. Even if their electoral fortunes were linked together through a Cutlerian tying arrangement as the CCS proposes, each candidate would still face powerful, and divergent, incentives about which constituency to please.

And, for that matter, the American voter would also face powerful and divergent incentives under the Cutler scheme. The option of voting a split ticket, so popular since the New Deal and the Great Society, would be denied. Hence, American voters would no longer be able to vote for their favorite recent option, both a President who tries to restrain growth in the size of the federal pie and an MC who tries to get "the folks back home" the biggest possible share of such pie as exists. What would American voters then do? I suspect Cutler implicitly assumes that his tying arrangement (coupled with four-year terms for House members, which he also favors) would tend to nationalize elections to Congress. Thus, he probably thinks he is doing something about the disturbingly localist redistributionist bias that pervades the House of Representatives and to a slightly lesser degree, the Senate.

But, actually, it is just as likely, if not more so, that Cutler's tying arrangement will have the opposite effect of localizing presidential elections and making the national electoral incentive structure worse. Given a choice between their local MC whom they know personally (and who has a demonstrated ability to bring home national pork), and a distant President who is largely ineffectual anyway, most ticket-splitting voters might well decide to go with their MC. If that happens, the Cutler plan may make matters far worse.

This is especially the case if we contemplate the redistributive incentives of a party-based government that has majorities in both Houses of Congress and that also holds the

lems of separation of personnel, as evidenced by his advocacy of the repeal of the Incompatibility Clause.

${ }^{107}$ Cutler, To Form a Government at 13-15 (cited in note 11). 
White House. Such a government would have every incentive to tax or burden disproportionately those geographical, or class, or racial minority groups that voted for the opposition while funnelling the benefits disproportionately back to itself. That scenario is one that is positively nightmarish for any government structure but particularly for one that must serve a large, geographically dispersed, heterogenous federation, like ours. The Cutler plan is thus potentially a recipe for secession, internal strife, and conceivably even civil war. It is a recipe for majority tyranny and minority ruin. Far better that we stick with the difficulties of our present electoral regime than move to this. Once again, this is a reform that is likely to make matters worse.

Again, the implications of the analysis here for the idea of party government are very, very pessimistic-more so than many may realize at first glance. The radically different electoral incentives created by our geographically based electoral system set powerful centrifugal forces in motion that will tend to rip any party government to shreds. The only way around this is to change the electoral system in some way that improves matters, and all the proposed changes that the CCS makes seem likely to make matters worse. ${ }^{108}$ The only reform I can think of that would improve this situation is the same reform that would help somewhat to counter the centrifugal anarchy unleashed by our ever-growing system of separation of personnel: Strengthen, within limits, the power of the President by giving him a lineitem veto and firm control over the executive "branch" of the government, but do not give him a French-style decree lawmaking power. ${ }^{109}$ That would begin to counteract seriously the congressional, localist bias without creating too much risk of national majorities burdening local minorities for their own benefit. ${ }^{110}$

\section{Geography}

A third feature of our constitutional system that greatly complicates the prospects for Cutlerian-style party-based gov-

106 For an explanation of why various posible reforms in the electoral system are likely to make matters worse rather than better, see Calabresi, 47 Ark L Rev (cited in note 79).

${ }_{109}$ A presidential decree lawmaking power is normatively troublesome for the same reason that Cutlerian party control of the presidency and of both Houses of Congress is troublesome. It raises the prospect of a national majoritarian officer redistributing national resources and loot from national minorities for the benefit of some transient national majority electoral coalition.

110 For a detailed and lengthy defense of this proposal, see id. 
ernment is the sheer size, populousness, and heterogeneity of the American polity. This anti-majority-party feature of the American constitutional regime was, of course, anticipated by Madison in Federalist $10,{ }^{111}$ but it is worth noting that the United States today is perhaps even more heterogenous than Madison might have imagined. Not only does today's "extended commercial republic" stretch from sea to shining sea, and from Point Barrow, Alaska, in the north, to Brownsville, Texas, on the Mexican border, but the enfranchised population it contains is far more diverse ethnically and socially than Madison could ever have imagined.

Indeed, the present-day pluralism of "factions" and of interest groups in the United States would probably stun the author of Federalist 10. This plurality of interest groups has thus worked even better than Madison could have hoped in complicating the life of those who would try to put together stable majoritarian factions, or parties, or political cartels in the United States. ${ }^{112}$ The formation of a stable majority political party or cartel in the legislature of an extended commercial republic like the United States is highly improbable, as Madison suspected it would be. This is the case for at least two reasons.

First, the extended size, economic structure, and political heterogeneity of the country make it hard to assemble permanent majority-party coalitions out of the great jumble of interest groups and factions that the society embraces. When such coalitions are assembled temporarily, say for a national presidential election, the many factional components of the coalition tend to discover that they have interests that conflict over time. As I wrote in 1982, "[t]he difficulty experienced even by the relatively popular Reagan Administration in maintaining its coalition of moderate Republicans, economic conservatives, and social conservatives furnishes one example." rienced by Democrats in holding together Franklin Roosevelt's New Deal electoral coalition furnish another.

The point is that, over time, it is difficult to prevent the interests of the various members of a coalition from starting to diverge. The various factions within the coalition often have con-

111 Federalist 10 (Madison), in The Federalist Papers at 71-84 (cited in note 2).

112 For a very brief discussion of some analogies between the theory of cartel breakdown in antitrust law and the theory of Madisonian pluralism, see Note, 91 Yale L J at 1406-1407 (cited in note 27).

113 Id at 1406 n 12. 
flicting preferences, priorities, and degrees of commitment to the coalition's project. And, the more such factions there are within the majority coalition, the harder it becomes to keep everyone happy at the same time. The differing preferences or utility curves of the coalition's members tend to pull the party cartel apart. Often it can only be put back together again temporarily, perhaps in opposition to the projects of some rival party cartel that manages, for example, simultaneously to offend moderate Republicans, economic conservatives, and social conservatives who otherwise would have only some values in common.

As in antitrust law, then, the more there exists a Madisonian pluralism of entities with differing utility curves, the harder it will be to keep a coalition of those entities together over time. This explains why Madison was basically right that permanent self-dealing majority political cartels are less likely in our extended commercial republic than they were in Ancient Athens or than they are today within the small confines of the City of Chicago. ${ }^{114}$ National political-majority coalitions in this country, either presidential coalitions or coalitions in Congress, are likely to have instability built into them that will curtail majoritarian self-dealing. These coalitions, indeed, often find themselves having to make extravagant bids for the votes of minority factional entities who care passionately about a single issue and whose votes are needed to keep the majority coalition in power. ${ }^{115}$

A second factor anticipated by Madison that complicates the task of those who would form permanent majority-party coalitions in the United States involves the "sheer numbers of people who must be brought together in a large democracy to form a popular coalition." ${ }^{116}$ Once again Madison foresaw this when he wrote in Federalist 10 that such numbers would create a communication problem by "making it hard for would-be oppressors 'to discover their own strength and to act in unison." 117 As Mancur Olson has explained, and as Madison foresaw, communication and organizational costs are comparatively lower for discrete and insular minorities than for large, amorphous, "silent majority"

11 Chicago, for example, has not had a Republican mayor in sixty-three years. See Bill Peterson, Bloom Bows out in Chicago, Wash Post A10 (Feb 16, 1989) (noting that Chicago's last Republican mayor, William Hale Thompson, was defeated by Anton Cermak in 1931).

115 See Note, 91 Yale $L J$ at 1407 (cited in note 27).

116 Id at 1408.

117 Id, quoting Federalist 10. 
coalitions. ${ }^{118}$ The cohesiveness of minority factions enables them to organize at lower cost than can the majority, and "[a]s the size of a polity expands, this organizational disparity steadily increases."119 Thus, the organizational advantages that minorities possess in city-states or in state governments tend naturally to expand as the size and heterogeneity of the regime expand. ${ }^{120}$

Madison's variety-of-interests argument and his organizational-costs argument are complementary and interdependent. ${ }^{121}$ As I have previously explained:

[L]ow organizational costs for minorities in Congress would be useless if that body were dominated by a stable majority coalition. State legislatures may be so dominated and may leave little room for minorities to exploit their organizational advantage. Similarly, the instability of congressional coalitions would not help minorities much if they could not afford to organize easily. Thus, large amorphous groups, whose organizing costs are high, have been relatively unsuccessful in Congress. Taxpayers and women can testify to this phenomenon. ${ }^{122}$

The end result is that the Madisonian argument of Federalist 10 has been proved right as far as it goes. It is very difficult to form stable majority-party coalitions or factions at the national level in a country as diverse as the United States. It is far, far more difficult to form such parties or factions here than it is in a smaller, more homogenous polity like England (or Chicago). This is so much the case that, if anything, a danger exists that minority factions, or "special interests" as we would call them today, may be too strong in an extended commercial republic like ours relative to the interests of (and the voice of) the "silent majority"!'123 Powerful social-structural forces that underlie our constitutional regime make it very, very difficult for majority-party coalitions to hold together for long at the national level. Perhaps that explains why both of our two major national political parties

118 See Mancur Olson, The Logic of Collective Action 53-65 (Harvard, 1965).

119 Note, 91 Yale L J at 1408 (cited in note 27).

120 See Frank H. Easterbrook, Unitary Executive Interpretation: A Comment, 15 Cardozo L Rev 313, 321 (1993) ("Madison, who in Federalist No. 10 so clearly saw the dangers of majority factions, did not foresee the strength of minority factions in a republic made smaller by changes in technology.").

${ }^{121}$ See Note, 91 Yale L J at 1409 (cited in note 27).

122 Id.

${ }^{123}$ See Easterbrook, 15 Cardozo L Rev at 321. See also Calabresi, 47 Ark L Rev (cited in note 79). 
are almost never able to hold onto the presidency for more than four, or eight, or twelve years at a time. ${ }^{124}$

What are the implications of these Madisonian geographical concerns for those who share Lloyd Cutler's preference for accountability-enhancing party-based government? I think there are multiple implications that cut in a number of different directions. First, and most obviously, an advocate of Cutler's approach should be somewhat discouraged and chastened by the prospect of the difficulty of constructing English-style party government in a federation as heterogenous as the United States. It is very, very unlikely, for the reasons Madison advanced in Federalist 10, that the Cutler project will work in the United States in anything like the way it works in England. Multiple contending social forces will tend to rip up majority party coalitions at a more rapid rate than Cutler may suspect. Accordingly, the very size and structure of our country may make the benefits of English-style party government largely unattainable here. Highly impermanent national party coalitions may not be able to offer the stable governance and accountability that are commonly thought to be advantages of the English constitutional approach. If that is the case, one must think long and hard about amending the Constitution as Cutler proposes when the prospects for success are so dim.

On the other hand, however, it could also be argued that Madisonian pluralism makes the prospect of American-style party government both less threatening and more necessary than English-style party government. Party government is made less threatening because the instability of majority-party coalitions would likely complicate their efforts to tyrannize minorities. This would be the case both because factions within the majority political coalition would have trouble holding together a plan of selfdealing and because such factions would know that there was a great likelihood that they, too, might very soon find themselves in the minority and in danger of finding their ox being gored.

121 The only exceptions since the expansion of suffrage during the Jacksonian Age are the Republicans' reign of twenty-four years between 1861 and 1884, their reign of sixteen years between 1897 and 1913, and the Democrats' reign of twenty years between 1933 and 1953. These are extraordinary exceptions, based on extraordinary circumstances that, in my judgment tend to prove the general rule. Moreover, we should not forget that these three extended periods of one-party rule included alternation between very different factions within the presidential party. The first period included Lincoln and Johnson; the second period included the laissez-faire McKinley and the Bull Moose Theodore Roosevelt; and the third period included FDR's New Deal and Harry Truman's more moderate liberal centrism. 
This latter factor might give all factions an incentive to encourage a political climate of moderation, since every faction could always be fairly sure that it would spend some time in power and some time out of power during any twenty-year period of time.

Thus, a Cutlerian might argue that American-style partybased parliamentary government would be less threatening to liberty than the English system, even though this advantage would be obtained at the loss of some degree of accountability. For some, this could tip the scales more in favor of giving Cutler's ideas a try. ${ }^{125}$

This is particularly the case since a Cutlerian could also argue that America's political problems today are a result of the fact that Madisonian pluralism works too well. Thus the explosion in the number of special interest groups over the last thirty years, and the increasing sophistication of the ways in which they organize, could be said to pose a real problem of "minority tyranny" in the United States, which Madison did not adequately anticipate. ${ }^{126}$ One might think Cutler's proposals could correct that problem by using parties as institutions that would mediate among special interests, binding them together into a more permanent majority coalition/cartel. Special ballot-access laws might be used to make it more costly for members of the majority cartel to stray-either to independent candidates like Ross Perot or to differing-party congressional candidates-as happens today when so many voters split their tickets ${ }^{127}$ to try to maximize their utility given their own unique bundles of factional interests. ${ }^{128}$

125 I am assuming here, of course, a two-party system of the sort that has existed for most of this country's history. Obviously, if one had a seven-party system, some of the smaller parties might be more cohesive and potentially more likely to tyrannize than are today's Republicans or Democrats. I think the presidential nature of our regime tends to encourage the two-party system because one needs national majority-party coalitions to win the presidency, which as some have remarked, is the only job in the system that anyone ever really seems to want. But this point may cut against Cutler since, as I have previously explained, his proposals could tend to weaken the presidentialist features of our constitutional system.

For evidence that presidentialism encourages two-party systems, consider the change in French politics from the Fourth Republic to the Fifth Republic of today. Although France currently has a multiple-party system, those parties seem increasingly grouped into two broad-based coalitions of the Right and Left for purposes of presidential politics. Sound familiar?

${ }^{126}$ See Easterbrook, 15 Cardozo L Rev at 321 (cited in note 120).

${ }^{127}$ The percentage of voters splitting their tickets in elections between 1972 and 1988 varied between approximately 20 and 25 percent. Sundquist, Constitutional Reform 11718 (cited in note 6) (discussing the 1972, 1984, and 1988 presidential elections).

${ }_{128}$ For every voter, these bundles must include differing preferences on economic, social, and foreign policy, as well as differing sets of geographical-distributional incentives. 
Such government reinforcement of majority political cartels would, of course, be the surest way to keep them together and to prevent factions from straying or cheating.

In summary, the implications of the Madisonian pluralist nature of our constitutional regime for party-based government are mixed. On the one hand, true English-style party-based government seems like even more of a pipe-dream than ever when we remember the complex factors we have been discussing that are at work. On the other hand, these disparate factors also make the need for unifying institutions of coalescence that will mediate among differing factional interests that much greater. At a minimum, though, these considerations suggest that the advocates of party-based government have a lot more thinking and explaining to do if they are to prove that their proposals will work as intended. American geography and heterogeneity make it very, very unlikely that political parties can be made to serve as cartel-type institutions of mediation.

\section{Decline of Party Strength}

In the three subsections above, I have tried to explain how three major features of our structural constitutional system make English-style party government much more difficult in this country than is commonly appreciated. Before proceeding, I should briefly allude to some other subconstitutional aspects of the structure of American law that complicate the task of those who would strengthen the mediating role of the political party in American life. Many of these points are well known but it is important that I not overlook them here as a result of my focus on constitutional law, practice, and structure.

One feature of modern American law that is very commonly singled out as having played a critical role in weakening parties is the advent of the distinctively American system of primary elections. ${ }^{129}$ As James Q. Wilson points out, American parties and party leaders have lost control over the nomination process and that, in turn, makes it very hard for those leaders to exert

Not only will the distribution of preferences vary enormously from voter to voter, but, importantly, of course, the degree of intensity with which preferences are held will vary as well.

129 See Everett Carll Ladd, Jr., Party "Reform" Since 1968: A Case Study in Intellectual Failure, in Patricia Bonomi, James MacGregor Burns, and Austin Ranney, eds, The American Constitutional System under Strong and Weak Parties 81, 87 (Praeger, 1981). See also Sundquist, Constitutional Reform 251-52 (cited in note 6) (discussing the effect of the presidential primary system on party unity). 
any real party discipline or control. ${ }^{130}$ Absent such discipline and control, party cohesiveness is undermined, and with it the potential that parties can be made to "stand for something," thus giving the polity a vehicle through which it can impose accountability.

The spread of the primary system and the demise of party caucuses has greatly accelerated over the years, and Cutler does not even dare to propose altering something that is widely believed to promote democratization and decentralization. Yet, if one wants to look for a cause for the weakening of parties, ${ }^{131}$ this change in the nation's electoral law is certainly a prime culprit. British-style party government is critically dependent on the power that party leaders in that country have over ballot access. If one truly wants more party government in this country, and more hierarchy in Congress and in the executive "branch," ballot-access law reform would probably be a good place to start.

Other features, as well, of state election law have tended in recent years to weaken political parties. Over the last fifty years, the states have moved away from rules that encouraged partyline voting and have restructured their ballots in a whole variety

130 Wilson, Political Parties at 22-23 (cited in note 3). The system of primary elections has made MCs "political entrepreneurs": they run campaigns largely on their own, and they appeal to voters as individuals rather than as members of a party. Demetrios Caraley, Elections and Dilemmas of American Democratic Governance, 104 Pol Sci Q 19, 29 (1989). Two other factors have contributed to the rise of political entrepreneurship. First, the decline in the importance of peer review for political advancement has allowed individual MCs to more easily resist party pressures. Michael J. Malbin, Factions and Incentives in Congress, 86 Pub Int 91, 95 (Winter 1987). Under the original Constitution, the only way House members could advance to the Senate or the Presidency was through review by political peers at the state or national level. Id. However, peer review has been largely eliminated with the direct election of Senators and the virtual direct election of the President. Id at 96. Secondly, the tremendous growth in the amount of campaign contributions by interest groups to individual MCs has freed the MCs from reliance on party funds and has allowed MCs to more easily resist party discipline. Cutler, 18 Pres Stud $Q$ at 487-88 (cited in note 11). See also Sundquist, Constitutional Reform at 266 (cited in note 6).

131 I am assuming here, as most people do, that there has been a weakening in recent years (certainly since 1900) in the cohesiveness of our two major political parties. The truth of this statement is suggested by: a whole host of things, including: (1) the recent rash of independent candidacies for the presidency, culminating in Ross Perot's extraordinary showing in the 1992 elections; (2) the decline of party-line voting in Congress, now made visibly evident in the difficulty President Clinton is experiencing at the hands of a Congress controlled by members of his own party; (3) the spectacular rise since 1960 of single-issue advocacy organizations; and (4) the unprecedented amount of ticket splitting that has occurred in federal elections since World War II, as compared to the prevalence of straight-party-ticket voting in elections held during earlier periods in American history. See, for example, Wilson, Political Parties at 18-26 (cited in note 3). 
of ways that encourage ticket splitting. ${ }^{132}$ This, of course, greatly increases the likelihood that different political parties will control the presidency, the Senate, and the House. ${ }^{133}$ In fact, there has been a great increase in the occurrence of divided government that has coincided with these changes in state election law. ${ }^{134}$ Many of these changes in state election law have been encouraged by the U.S. Supreme Court. Through its modern-day interpretations of the now-incorporated First Amendment, and through its one person, one vote case law on redistricting, ${ }^{135}$ the Court has expanded ballot access ${ }^{136}$ in both formal and real ways, thus strengthening the hand of the individual voter and weakening the hand of the leadership of the political parties.

Thus, reforms in state election law, both those required by the federal courts and those the states have been tending to make on their own initiative, have undermined the American political party. Federal election law reforms may have contributed to this trend as well. By strengthening Political Action Committees ("PACs"), federal election law reforms in recent decades have been said to have weakened the hand of the old-line party machines. ${ }^{137}$ This too, then, has contributed to making it harder

132 See Sundquist, Constitutional Reform at 112-13 (cited in note 6).

133 This, in turn, illustrates the extent to which our fundamental governmental structure and "Constitution" continue to rest on a foundation of state election law that can be changed quite easily without any need for constitutional amendments. Akhil and Vik Amar have pointed out that we could elect Vice Presidents independently from Presidents if we simply amended state election laws to allow voters to split their tickets. Amar and Amar, $78 \mathrm{Va} \mathrm{L} \mathrm{Rev} \mathrm{at} \mathrm{918-27} \mathrm{(cited} \mathrm{in} \mathrm{note} \mathrm{54).} \mathrm{Others} \mathrm{have} \mathrm{argued} \mathrm{for} \mathrm{changing} \mathrm{the} \mathrm{way}$ we choose presidential electors, at large, by amending state election law. Similarly, it seems likely that the Cutlerian straight party ticket could be achieved simply by amending state election law, without a constitutional amendment! It is thus remarkable how much of our basic electoral structure remains under the control of the states at the subconstitutional level. Of course, the fifty states may face serious collective-action problems when it comes to changing their election laws, as term-limit advocates have discovered.

134 See Calabresi and Larsen, 79 Cornell $\mathrm{L}$ Rev (cited in note 11). See also Sundquist, Constitutional Reform at 111-16 (cited in note 6).

${ }^{135}$ See Reynolds $v$ Sims, 377 US 533, 568 (1964) (announcing the one person, one vote rule); Baker v Carr, 369 US 186, 208-237 (1962) (declaring redistricting challenges to be justiciable). See also Daniel D. Polsby and Robert D. Popper, Ugly: An Inquiry into the Problem of Racial Gerrymandering Under the Voting Rights Act, 92 Mich L Rev 652 (1993) (analyzing recent Supreme Court doctrine on the Voting Rights Act, which has been applied by the Court to alter state election law).

${ }^{136}$ For a treatise summarizing much of the modern Supreme Court's case law on rights of political participation, see Laurence H. Tribe, American Constitutional Law 1062-1153 (Foundation, 2d ed 1988).

137 For a full discussion of the many legal changes that have undermined the party system, see Winter, 15 Ga L Rev 1 (cited in note 9); Bickel, The New Age of Political 
for the American political party to function as a mediating institution.

Aside from changes in election law, another area of nonconstitutional legal change that has weakened the parties has come from reforms in the rules of Congress, particularly the rules of the U.S. House of Representatives. ${ }^{138}$ Wilson described how such reform efforts brought down Joe Cannon, the powerful onetime Speaker of the House. ${ }^{139}$ But, in addition, it is well known that the post-Watergate 1974 elections led to a great change in the Rules of the House that weakened the party leaderships and strengthened the hand of the party caucuses. The seniority system was abandoned in part, which may have led to an erosion in party unity since, absent advantages to seniority, party members may have less of an incentive to toe the party line in close cases. In addition, it may also be the case that hotly contested primaries are more likely in a regime where there is no advantage (or less of an advantage) to having a Member with a lot of seniority. The net result is to augment the weakening of the parties already under way for the reasons given above. This, in turn, tends to accentuate the already excessive tendency of the nation's representatives to focus on the needs of their districts at the nation's expense.

A final feature of our present legal regime that has shaped the political climate that faces our two major parties is the result of technological and regulatory changes in the communications industry in recent years. ${ }^{140}$ The substantial deregulation of that industry, coupled with the revolutionary growth of cable television, of broadcasting, and of competition in telecommunications, ${ }^{141}$ has arguably made political parties as we once knew them almost obsolete. Ross Perot has proven that no presidential contender needs a party to get his or her message across, so long

\footnotetext{
Reform (cited in note 9).

${ }^{133}$ See Sundquist, Constitutional Reform at 258-64 (cited in note 6).

139 See Wilson, Political Parties at 24-25 (cited in note 3).

140 The growth in number of media outlets providing political information to the voters has weakened political parties. The parties themselves used to be the primary providers of political information to the voters. Ladd, Political "Reform" Since 1968 at 86 (cited in note 129). The advent of television and computer public-opinion polls have directly linked voters to individual legislators, bypassing, and thus weakening, political parties. Arthur M. Schlesinger, Jr., Can the Party System Be Saved?, in Patricia Bonomi, James MacGregor Burns, and Austin Ranney, eds, The American Constitutional System under Strong and Weak Parties 115, 119 (Praeger, 1981).

${ }^{141}$ See generally Harvey M. Sapolsky, et al, eds, The Telecommunications Revolution (Routledge, 1992).
} 
as they have enough money (or wit) to figure out how to get television coverage. Thus, it could be said that the unleashing of the electronic media through deregulation has to some degree rendered the parties obsolete as mediating institutions.

Voters are able to (and want to) form their own impressions of candidates and of their policy proposals. Likewise, voters are able to (and want to) form their own views on single-issue campaigns, often led skillfully by lobbyists/advocates, unaffiliated with either party, and based in Washington, DC. These trends are, in turn, greatly exacerbated by federal election law, which limits candidate contributions by political parties but leaves many other types of campaign contributions relatively unregulated. Federal election law may also encourage the growth of singleissue advocacy organizations relative to political parties. It is highly doubtful whether any or all of this has been entirely a happy development. ${ }^{142}$

In sum, there are numerous features of our subconstitutional legal regime, which are widely recognized, that tend to discourage the formation in this country of hierarchical, Britishstyle political parties. ${ }^{143}$ These subconstitutional legal rules supplement a constitutional superstructure that we have already shown is very hostile to the institutional mediation by political parties of the kind that occurs in other countries and of the kind that Lloyd Cutler advocates for us. We are left thus to conclude that the American political landscape has been relatively unfriendly to political parties from the outset, and that in some important ways it has been getting even less friendly, at least since 1900. Why then do political parties form at all in the United States, and what does the fact that they do mean for Lloyd Cutler's proposals for enhancing party-based government? These two questions form the two subjects of inquiry for the discussion in Section III below.

${ }^{142}$ See Winter, 15 Ga L Rev 1 (cited in note 9); Bickel, The New Age of Political Reform (cited in note 9).

143 whe roots of incoherence of policy which lead many critics to wish to amend the U.S. Constitution do not come from the Constitution but rather from the unwritten constitution-the fixed political customs that have developed without formal Constitutional amendment, but that have been authorized by statute or frozen, at least temporarily, in tradition." Don K. Price, America's Unwritten Constitution: Science, Religion, and Political Responsibility 9 (Louisiana State, 1983). The elements of the unwritten constitution that arguably lead to what some perceive as incoherence of policy include party conventions, the primary system, the congressional committee system, and technological advances such as television. Id. 


\section{TOWARD AN AGENCY-COST ANALYSIS OF AMERICAN POLITICAL PARTIES}

We established at the outset that the Framers were very hostile to the idea of parties, and that they deliberately designed our constitutional structure to discourage them. And, we have also seen that in many ways they did their work better than they knew: numerous aspects of our constitutional structure discourage party cohesiveness and growth. Finally, we have seen that numerous widely remarked-upon features of the subconstitutional legal system tend increasingly to complicate the life and health of broad-based American political parties.

This raises the question of why it is that American political parties still exist. Put another way, what social functions, "mediating" or otherwise, do the two major American parties play to justify their continued existence? Are they only electoral vehicles of convenience to be used on occasion by politicians seeking office? Or do they do some other things of general social value as well? Generating at least some tentative answers to these questions is vital to assessing Lloyd Cutler's call for constitutional amendments that would strengthen the parties. Given the difficulty of the task at hand, the arguments for parties would have to be quite strong before one would set out to amend the Constitution to try to overcome the host of factors I have described that stand as obstacles to Cutlerian-style party-based government.

Cutler himself identifies the value of the parties as stemming largely from their potential to enhance accountability in a government system where the separation of powers makes that hard. ${ }^{144}$ That is surely one main part of the argument for political parties with which the reader should by now be thoroughly familiar. Related to that, however, are a number of other points of some consequence. For example, as Richard Hofstadter points out, the existence of the idea of a party system means an acknowledgement by those in authority of the legitimacy of a legal opposition that may some day be asked to form a government. ${ }^{145}$ That means that the party system and the existence of party labels help to promote and support the notion that opposition to government programs and policies may have some long-

144 See Cutler, To Form a Government at 1-17 (cited in note 11); Cutler, 18 Pres Stud $\mathrm{Q}$ at 490-91 (cited in note 11); Cutler, $30 \mathrm{Wm}$ \& Mary L Rev at 387-402 (cited in note 11).

145 See Hofstadter, Party System at 4-5 (cited in note 21). 
term systemic legitimacy. When Republicans criticize Bill Clinton's health-care plan or when Democrats criticized Reagan's tax cuts, there was an "official," legitimate quality to the criticisms because they were made by, and on behalf of, our two national political parties and their official spokesmen.

Thus, the existence of a party system serves social goals not only because it renders the government accountable for a platform-and even in America, with our two very weak parties, some of that kind of party accountability most certainly exists-but also because the party system makes the "loyal" opposition both accountable and more legitimate. Both American political parties, whichever one is in power at a given point and whichever one is not, are accountable over time to their constituencies. They have groups that they speak for and a place in history that they have occupied, and that they wish to continue to occupy. Doing this requires that the parties maintain their reputational brand capital over time. This, in turn, imposes some degree of accountability on them, and, most importantly, on the countless numbers of officeholders who would draw on party brand capital over time.

The reputation value of party labels, and the accountability enhancement that goes with that, suggests something additional about the nature of the "mediating" social function played by American political parties. In a way, what the parties really do is perhaps most precisely described as reducing what could be called "the agency costs" that are associated with a whole host of noncontractual agency relationships that exist in the political system. ${ }^{147}$ These agency relationships include at a minimum: 1) the noncontractual agency relationship of the voters to those of their agents who actually hold high political and governmental offices; 2) the agency relationship of the President to all

${ }^{146}$ See Jonathan R. Macey, The Role of the Democratic and Republican Parties as Organizers of Shadow Interest Groups, 89 Mich L Rev 1 (1990) (insightfully discussing many of the ways in which political parties reduce at least some agency costs). Professor Macey also provides a thoughtful summary and critique of the traditional approach taken by political scientists and economists to political parties. Jonathan R. Macey, Packaged Preferences and the Institutional Transformation of Interests, $61 \mathrm{U}$ Chi L Rev 1443 (1994) (pointing out the extent to which political parties shape the preferences of their voters and thus denying that the parties are exclusively "agents" of their voters).

147 For a good introduction to the concept of agency costs in corporate law, see Michael C. Jensen and William H. Meckling, Theory of the Firm: Managerial Behavior, Agency Costs and Ownership Structure, 3 J Fin Econ 305 (1976); Eugene F. Fama, Agency Prob. lems and the Theory of the Firm, $88 \mathrm{~J} \mathrm{Pol} \mathrm{Econ} 288$ (1980); Eugene F. Fama and Michael C. Jensen, Separation of Ownership and Control, 26 J L \& Econ 301 (1983). 
those nonlegislative and nonjudicial officers who are, in theory at least, his agents committed to assisting him in "faithfully executing the laws"; 3) the comparable, if less hierarchical, agency relationship of the leading institutions and officers of the legislative and judicial "branches" to all the subordinate committees, courts, and officers who are their agents for purposes of legislation or adjudication; and 4) the very loose agency relationship that exists, as a result of the constitutional separation of personnel, between the congressional committee and subcommittee chairmen and all the executive "branch" personnel whom they must confirm and "oversee" and who, in turn, actually spend the money that Congress appropriates and enforce the laws that it enacts.

In all four of these situations, ${ }^{148}$ a kind of largely noncontractual agency relationship exists ${ }^{149}$ between the four identified categories of principals (We the People (or the relevant primary and general-election voters among them), the President, congressional and judicial leaders, and the committees) and the four identified categories of agents (all government officers, all executive officers, all legislative and judicial personnel and staff, and the cabinet departments and other related entities). In every one of these instances, the agency relationship mentioned above generates agency $\operatorname{costs}^{150}$ of the kind described by Jensen, Meckling, and Fama in the corporate-agency-theory literature. ${ }^{151}$

148 There are, of course, countless additional agency relationships in government beyond these four, but the four I have listed are among the most basic, and it will suffice to make my point about political parties to confine what I have to say to those four.

149 I say "largely" because there is a sense in which the social contract of the Constitution, for example, binds government officers to be the faithful agents of "We the People," just as there is a sense in which subordinate executive officials have an employment contract with the government that makes them the agents of the President for purposes of law execution. The point is that these agency relationships are not "contractual" in the same sense that corporate agency relationships are contractual. The contract is generally not written down and it is rarely, if ever, enforceable in court. Nonetheless, many of the same problems of how to reduce agency costs occur in this context, just as they do in the corporate context. It thus seems fruitful to make the analogy here.

${ }_{150}$ For a discussion of agency costs and our constitutional structure, see Jonathan $R$. Macey, Transaction Costs and the Normative Elements of the Public Choice Model: An Application to Constitutional Theory, $74 \mathrm{Va}$ L Rev 471 (1988). See also, Macey, $61 \mathrm{U}$ Chi L Rev at 1467 (cited in note 146) (Macey discusses powerfully how the U.S. Constitution raises "the decision costs of government [thus permitting] disengagement by enabling citizens to avoid the costs imposed by rent-seeking without incurring the substantial costs of organizing into effective political coalitions in order to deter unwanted governmental activity.").

151 See note 147. 
What this means in practice is that in all four types of government agency relationships listed above, the interests of the principals diverge from the interests of their agents, at least to some significant degree. The agents have an incentive to engage in self-dealing; the principals have an incentive to try to rein them in. The end result is that agency costs are generated. These are defined as the sum of: 1 ) the monitoring costs (in money and otherwise) to the principals of monitoring their agents to try to limit their self-dealing undertakings; 2) the bonding costs (in money and otherwise) to the agents of trying to reassure the principals that their wishes will be followed; and 3) the residual losses that neither monitoring nor bonding can ever eliminate entirely.

The problem occurs directly in government because the separation between the sovereign people and their managers (and their managers' agents) mimics many of the problems that arise in corporate law because of the separation of ownership and control. I do not want to overstate the analogy, ${ }^{152}$ but very real similarities do exist. If anything, some factors may cause agency costs to be especially and uniquely high where governmental agency relationships exist. Power may create opportunities for self-dealing that are even more irresistible than those created by money, at least for some people. The absence of an agency contract that is judicially enforceable may lead to greater divergence in politics between the interests of the principals and of the agents than is the case in corporate law. The fact that one cannot give significant ownership shares to political agents in the form of stock options, while one can and usually does do so in the corporate-law context, may make it harder in political agency relationships to tie together the interests of principals and of agents. ${ }^{153}$

In sum, a whole host of factors confirms what common sense readily suggests: the theory of constitutional, democratic governance must wrestle with the problem of agency costs just as corporations must wrestle with it. The minute you abandon direct plebiscitary democracy for a republican system of representa-

${ }^{162}$ Corporate contractual agency relationships do differ in a whole host of important ways from political agency relationships. One very important difference already mentioned is the availability of judicial enforcement of the contract in court.

${ }^{163}$ There are also, however, countervailing factors that especially constrain agency costs in the political sphere; for example, political agents must generally run for reelection or seek reappointment, while corporate agents often do not need to do so. On the other hand, political agents often serve for a fixed term while many corporate agents can be fired at will. 
tion, you must either posit the existence of a political class that is more virtuous than the citizenry or expect that there will be agency costs. The agency costs may be worth enduring, indeed they may to some degree be a good thing, if you are skeptical about the desirability of direct plebiscitary democracy, as I am. Thus, Burkeans have always subscribed to the notion that political representatives ought to pursue their own agenda to some degree and should not simply vote for what "the District" wants them to. Thus, I by no means wish to suggest that agency costs in politics are all bad: indeed, I would not choose to eliminate them altogether, even for a minute.

Nonetheless, political agency costs can present a problem in many contexts when wholly self-interested self-dealing sets in. ${ }^{154}$ The more opportunities that exist for the political class to engage in such self-dealing, and the more readily politicians are able to live under rules and conditions other than those that prevail for the general citizenry, the worse the problem of agency costs becomes. When the costs become really high, the voters and citizenry try to deal with them by realigning the interests of their agents with themselves through such devices as term limits. Term limits reduce agency costs by making the agency relationship one of fixed duration, thus forcing the officeholder to govern in the expectation that he will soon again be a principal and will lose his agency self-dealing potential.

Now where do political parties fit into all of this? Well, fundamentally, I think they are a device by which the voters attempt to limit political agency costs by tying tens of thousands of office-holding political actors to a fairly defined set of programs and ideas for which they will ultimately be held accountable. ${ }^{155}$

154 As my colleague Dan Polsby has reminded me, such self-dealing need not involve only the obvious financial forms of corruption. It also includes all those many public officials who sell out their principles for a few words of praise from our major national newspapers and television networks.

${ }_{155}$ In his very insightful and thought-provoking contribution to this Special Issue, Professor Jonathan Macey agrees with me that important analogies can be drawn between public corporations and political parties as institutions that work to reduce agency costs and facilitate efficiency-enhancing disengagement. Macey, $61 \mathrm{U}$ Chi L Rev 1443 (cited in note 146). But Professor Macey unfortunately goes on to misunderstand me when he suggests incorrectly that I take "the view that people join political parties with [entirely] fixed preferences about issues ...." Id at 1461. I do not believe that people's views on the whole range of public-policy issues are totally fixed when they join a political party, and I agree with Professor Macey that parties play an important role in shaping some of the less important policy views of their members.

My disagreement with Professor Macey is on the extent to which parties shape their members' preferences rather than acting as agents for their members. I believe the rela- 
By doing this, political parties limit the opportunities for selfdealing that would otherwise exist. At the same time, political parties devote significant resources to monitoring their officeholding members to make sure that they do not go off on frolics and detours rather than serving as faithful agents. ${ }^{156}$

This monitoring goes on in all four of the governmental agency relationships I listed above. Primary and general-election voters monitor the faithfulness of party agents to their party principles (and platforms); Republican and Democratic presidents monitor the faithfulness of their party's political cabinet and subcabinet employees, dismissing or denying promotions to those who prove to be faithless; partisan congressional and nominally nonpartisan judicial leaders ${ }^{157}$ monitor fellow-party-member MCs and inferior courts, whipping or reversing them into line; and party Committee Chairmen monitor the faithfulness of those political appointees whom they have allowed to be confirmed or to whose departments they continue to appropriate funds. The

tionship is predominately an agency relationship and that party members' views are "transformed" only on relatively peripheral issues about which the party members have no strong preference.

I also disagree with Professor Macey that "political parties offer no mechanism through which [they] can control members who stray from the party line." Id. To the contrary, parties routinely discipline their faithless agents in primary elections by denial of promotions, and, occasionally, by dismissal. I have personally observed this process occurring many, many times!

Finally, I disagree with Professor Macey's claim that "political parties in America differ from one another only marginally with respect to their programs and ideas." Id. My personal experiences working in the Reagan and Bush White Houses, in the Senate, on two national presidential campaigns, on Senate and House campaigns, and in the Rhode Island governor's office lead me to believe that the Democratic and Republican parties send out the very strongest ideological signals they can, while maintaining the potential to assemble 51 percent majorities in whatever electoral constituency they are then contesting. This is not, of course, to deny that our two parties have ideologically differing regional wings or that they have a centrist orientation compared to the political parties of other nations with different electoral structures.

These quibbles aside, I largely agree with Professor Macey's analysis of political parties, which seems to me to be quite similar to my own. The minor differences between us are insignificant compared to the points on which we agree.

${ }_{166}$ See Macey, 89 Mich L Rev at 20, 28 (cited in note 146) (discussing how political parties monitor politicians on behalf of shadow interest groups, thus reducing the costs for those groups).

${ }^{257}$ Obviously, the judiciary is less political than the two policy-making "branches" because judicial life tenure is designed to maximize agency costs. Federalist 51 (Madison), in The Federalist Papers at 321 (cited in note 2) ("[T]he permanent tenure by which the appointments are held in that department must soon destroy all sense of dependence on the authority conferring them."). The system does not work as well as it might because the possibility of promotion leaves many judges, incredibly even some Associate Justices of the Supreme Court (who seek the Chief Justiceship), more dependent on the political appointing authorities than Madison may have realized. 
parties facilitate such monitoring by generating information, by identifying potential office holders who have high potential to be faithful agents, and by receiving and addressing complaints from party members when self-dealing occurs and then triggering disciplinary action by those of the parties' agents in government who have remained faithful. The existence of party organizations and their web of affiliations thus reduces monitoring costs, information costs, and the costs of self-dealing. This is because the party leadership has an incentive to keep these costs tolerable so that the brand capital of the party's reputational "good will" will be intact when the next election rolls around. ${ }^{158}$

The parties' reputational "good will" in turn represents a form of "bonding"159-that is to say, the parties invest resources in maintaining their reputations because doing so helps to assure primary and general-election voters that the party's candidates will be faithful agents if elected and that never again will those agents go off on a Watergate- or Whitewater-style frolic and detour of self-dealing. At various times in our history, and in varying electoral constituencies, both the Democratic and the Republican parties have tried to prove that they are the party of "clean government" while their opponents are the party of the "corrupt machine."160

The resources the party leaders and office-holding members invest in this reputational exercise represent bonding costs. Obviously, individual office holders worry about their own individual reputations first and foremost. But party reputation counts too, especially where the presidency is at stake, with the thousands of associated patronage positions. When one party has been in office for a long time, and the other is challenging, party reputation for clean and energetic good government may become especially important. In some election years, running under the label of the idealistic party that has been out of power is as helpful as having the "Good Housekeeping Seal of Approval." Other times that seal of approval comes from a candidate's association with the reputa-

158 Of course, the parties have their own problem of agency costs with their leaderships. Loyalists are always heard to complain in Washington that some President, Democrat or Republican, is just using the party to promote his own personal electoral interests while leaving the congressional and state party members out to dry.

${ }_{159}$ See Macey, 89 Mich L Rev at 3 (cited in note 146) (Parties "provide a mechanism by which politicians can make credible (bonded) promises to" shadow interest groups.).

${ }_{160}$ Some external groups, like Common Cause, may also help individual office holders with whom they are closely identified in certifying themselves to the public as being corruption free. 
tion of a proven faithful party agent-a Ronald Reagan or a Franklin Roosevelt. Association with the label of a faithless party agent ("Read my lips! No new taxes!") can in turn prove to be very dangerous to a candidate. Party labels thus matter for the reassurance they convey. ${ }^{161}$ In that sense, parties as "mediating institutions" serve a real function in our society and are desirable to boot.

There are a whole host of other agency costs that political scientists have at times mentioned that parties tend to reduce. For example, the existence of party structures may reduce the costs of legislative/executive bargaining by giving the President a few legislative leaders he can deal with, thus saving him time and resources. ${ }^{162}$ For those who believe there is an "iron law of oligarchy," parties provide a mechanism by which the inevitable oligarchic elite can implement its program. ${ }^{163}$ The parties reduce agency costs by providing a continuous source of feedback from the voters about how party members in office are doing. ${ }^{164}$ Realignments of party memberships warn the political elite of changes occurring in the electorate's desires. ${ }^{165}$ In addition, as Jonathan Macey points out, political parties reduce certain transaction costs by providing "the forum through which [ ] interest groups can trade support with each other." ${ }^{166}$ Parties thus allow politicians to diversify and specialize on the issues of one interest goup, while retaining the support of other interest groups committed to the part coalition. Political parties, like firms, reduce transaction costs because both "replac[e] the price mechanism that characterizes market transactions with the long-term contracting that characterizes firms and political parties."167 As Macey insightfully explains:

The politicians who constitute a political party represent a whole set of nondiversifiable investments in a wide range of policy issues and positions. Party membership allows party

181 See Leon D. Epstein, Political Parties in Western Democracies 315 (Praeger, 1967) (discussing some functions of party labels).

${ }_{102}$ See Wilson, Political Parties at 32-33 (cited in note 3).

163 See Robert Michels, Political Parties: A Sociological Study of the Oligarchical Tendencies of Modern Democracy 393-409 (Free Press, 1915).

${ }^{161}$ See Sartori, Parties and party systems: at 56-58 (cited in note 21).

${ }^{265}$ For a classic study of party realignments in the United States, see James L. Sundquist, Dynamics of the Party System: Alignment and Realignment of Political Parties in the United States (Brookings, 1983). See also Richard L. Rubin, Party Dynamics: The Democratic Coalition and the Politics of Change (Oxford, 1976).

166 Macey, $61 \mathrm{U}$ Chi L Rev at 1462 (cited in note 146).

157 Id at 1464-65. 
members to diversify their investments in policy issues, to disengage from a wide range of issues, and hence to specialize in a small number of policy areas. At the same time, when an individual politician runs for reelection his party membership enables him to claim credit for the accomplishments of his party, even those for which he was only tangentially responsible. ${ }^{168}$

In sum, political parties provide a whole bundle of valuable benefits, which explains why they continue to exist in the United States and why they serve, for example, as good predictors of legislative voting behavior. ${ }^{169}$ Even if our constitutional structure makes British-style Cutlerian party government unlikely, that does not mean that parties do not serve a useful purpose. American parties combine the labelling function of the Good Housekeeping Seal of Approval with all sorts of other informational functions. They are invaluable for the work that they do in keeping agency costs down and in providing some degree of accountability. It is no wonder that American political parties continue to exist notwithstanding our historical and constitutional suspicion of "party government." So long as the parties remain in the roles I have identified herein, there is little that is problematic with them and probably much that is good.

Whether parties as reducers of agency costs deserve to be praised as good "mediating institutions" is a matter of definitions. One could as easily and as justifiably praise the folks at Good Housekeeping on this rationale, but this is not how the phrase "mediating institution" is usually used. Most of the modern Tories that I know would be deeply puzzled by the notion that the folks at Underwriters Laboratories ("UL approved") run a "mediating institution." If party labels are significant mainly for the information they convey, and if parties are valuable mainly as agency-cost-reducing devices, then this lends a new meaning to the concept of the desirable "mediating institution."

This brings me, at the end of a long and very complicated argument, back full circle to the question I began with: Is Lloyd Cutler right that we should amend the Constitution in the ways he proposes to create "party government"? Put another way, do the arguments that explain the good that parties do and why

168 Id at 1464.

169 See Wilson, Political Parties at 29 (cited in note 3) ("[T]he single best clue to how a congressman will vote is his or her party affiliation."). 
they exist in the U.S. in the face of many obstacles, coupled with the systemic failures of our constitutional system, ${ }^{170}$ warrant the creation of stronger party systems to mediate between the individual citizen and the government? Such mediation, we are told, would promote accountability. It would overcome gridlock and make government more responsive. ${ }^{171}$ Put another way, it would further reduce agency costs and give the citizenry what it really wants.

Well, as must be all too obvious by now, I am unpersuaded. First, I think the Framers were right, as I indicated in Section I, to be suspicious of party government. The idea of parties or factions using the machinery of government for their own ends is one that frightens me, as it frightened Washington and Madison. I do not find the idea of an all-powerful Tory or Labour Party Government to be at all appealing. ${ }^{172}$

Second, Cutlerian-style party-based government would have to overcome enormous hurdles to be made to work in this country, given the ways in which our constitutional and electoral systems tend to make party-based government difficult. Our constitutional structure of separation of personnel, the centrifugal forces unleashed by the geographical biases created by the electoral system, and the plurality and heterogeneity implicit in our continental size and large population all work to make Cutlerian party-based government very, very difficult. Even if these factors could somehow be overcome, the creation of a

170 I have assumed, for the sake of argument only, that there are systemic failures in our consitutional system. This assumption has been an article of faith in the political science profession for at least forty years. See American Political Science Association, 44 Am Pol Sci Rev supp at 1-5 (cited in note 6). Two political scientists have recently raised very powerful challenges to this assumption. David Mayhew, for example, argues brilliantly that "unified as opposed to divided control has not made an important difference in recent times in the incidence of ... important legislation." David R. Mayhew, Divided We Govern 4 (Yale, 1991). See also Charles O. Jones, The Presidency in a Separated System (Brookings, forthcoming 1994). But see Sundquist, Constitutional Reform at 102, 106 (cited in note 6) (challenging Mayhew's conclusions).

${ }^{171}$ It is by no means obvious to me that ending gridlock is desirable. Cass Sunstein has argued that we should not presumptively favor existing distributions of property and rights. Sunstein, 87 Colum L Rev 873 (cited in note 51). If that is so, we also should not presumptively favor contingent future distributions either. Yet, as Dan Polsby has pointed out to me, that is precisely what we do when we presume that gridlock is bad.

${ }_{172}$ One friend colorfully characterizes Cutler's argument as resting on the syllogism that because party government works in the United Kingdom it will work here. As he points out, this is like saying that a baboon's liver ought to be transplantable into a human being because the similarities, macro and micro, between human beings and baboons are much more important than the differences. The procedure for establishing the putative fact is simply to assert it, a methodology that dependably leads to error. 
British-style party-based government would still require undoing major changes that have occurred in our state and federal election laws, in the Rules by which Congress is governed, and in the communications media. I strongly doubt that any of this could be done, ${ }^{173}$ and I do not think it would be desirable if it were. Cutler's proposed constitutional amendments are doomed to fail, even to accomplish their underlying goals. The creation of party-based accountability requires far more constitutional amending than Cutler seems to realize.

Third, political parties already play a useful role in this country; that, indeed, is why they continue to exist. They provide information, they reduce agency costs, and they guarantee a modicum of accountability. All of this is a good thing. It does not establish, however, the quite different proposition that Britishstyle party-based government would also be a good thing. Just because we think that the Good Housekeeping Seal of Approval is efficiency enhancing does not mean that we should endorse as well a Good Housekeeping-sponsored, horizontal-price-fixing cartel. Similarly, just because parties provide a valuable labelling and agency-cost-reducing service to voters does not mean that they should be turned into fearsome combinations of dangerous and easily abused governmental power.

American-style political parties are a good thing as they presently exist. Like Ralph Winter, I regret some of the postWatergate reforms that have undermined them and strengthened special interest groups in their stead. ${ }^{174}$ But to move in the direction that Cutler proposes is impossible and undesirable for all the reasons listed above. Whether parties as agency-cost reducers (but not as governors) qualify as "mediating institutions" depends on what definition of "mediating institutions" one wants to use. But I am certain that parties are socially desirable to the extent that they function in the agency-cost-reducing ways I have described. I tend to think they would not be socially desirable if they functioned in the cartel-like fashion that Lloyd Cutler seems to want them to adopt.

In closing, I should note that as I implied in Section II, I think Cutler is on to something when he decries the localist decentralization of our government. Sometimes that, in effect, is

${ }^{173}$ For example, it is difficult to imagine individually powerful MCs voting to amend the Rules of the House or Senate and giving up some of their own power. James $Q$. Wilson, Does the Separation of Powers Still Work?, 86 Pub Int 36, 52 (Winter 1987).

174 See Winter, $15 \mathrm{Ga}$ L Rev 1 (cited in note 9). 
what Cutler means to criticize when he attacks the problem he calls gridlock. But the solution to this problem, as I have argued elsewhere ${ }^{175}$ is to strengthen the hierarchy of the unitary executive headed up by our nation's only nationally elected officer-the President. ${ }^{176}$ That reform, coupled with a repeal of some of the post-Watergate rules that weakened the amount of hierarchy in Congress by undercutting the congressional leadership, is all the constitutional reform this country really needs.

\section{CONCLUSION}

The Framers of the Constitution were opposed to the idea of party-based government, as they understood it, for reasons that remain basically sound today. Accordingly, they deliberately designed our constitutional structure to inhibit all forms of partybased government, thus unintentionally foreclosing any possibility of an emergence in this country of the then-unbeknownst British style of parliamentary government. They did their work better than they knew. The resulting constitutional system of separation of personnel, of geographically centrifugal interests, and of a radically pluralistic social structure makes British-style "party government" almost impossible in this country. Additional subconstitutional legal developments have only complicated matters further. Notwithstanding this, political parties continue to exist in this country because, although they do not govern, they nonetheless play a valuable labelling role, and they reduce agency costs. This is the most we can or should expect of them, however. Proposals like those advanced by Lloyd Cutler to enhance their role are unlikely to work as intended and would probably aggravate our problems of governmental structure rather than lead to improvements.

The lesson of all of this for the theory of mediating institutions is that party mediation between the individual and the state is good when it takes the form of providing information and largely harmful and dangerous when it leads to state coercion of private individuals. I think this is the case for reasons of political philosophy that largely transcend the issues at hand.

175 See Calabresi, 47 Ark L Rev (cited in note 79).

178 The Vice President is nationally elected as well, of course, but he has little real power. 
